\title{
ECOLOGICAL LAND-USE PLANNING AND CARRYING CAPACITY EVALUATION IN THE JALAPA REGION (VERACRUZ, MEXICO)
}

\author{
GERALD G. MARTEN* and LUIS A. SANCHOLUZ
}

Instituto Nacional de Investigaciones sobre Recursos Bioticos, Jalapa, Veracruz (Mexico)

(Accepted 9 March 1982)

\begin{abstract}
Marten, G.G. and Sancholuz, L.A., 1982. Ecological land-use planning and carrying capacity evaluation in the Jalapa region (Veracruz, Mexico). Agro-Ecosystems, 8:83-124.
\end{abstract}

A practical approach for the inclusion of environmental factors in land-use planning is presented. The Jalapa region, an area of $4750 \mathrm{~km}^{2}$ which embraces a diversity of ecological conditions, is used to illustrate the approach. Data were gathered from aerial photographs, a survey of maize fields and interviews of farmers concerning their cultivation practices.

After devising a climatic and geomorphological system of land classification, 33 land types were identified, described and inventoried; 58 land-use systems were identified and described. The descriptions were structured to predict the income, employment, costs, food production, agricultural chemical inputs and erosion that could be expected for each land-use system on each land type. This information was used to devise a multi-objective land-use game for planners. Users of the game may set priorities on their planning objectives, specify the amounts of agricultural services available, and see the effects these have on optimal allocation of the available land of each type among the different possible uses, as well as how well the objectives are satisfied by the allocation.

By shifting objective priorities and varying infrastructure levels, the game user may examine the trade-offs among planning goals and among possible avenues of investment or other management interventions. A study of the environmental cost of producing increasing amounts of food for a growing population in the Jalapa region illustrates the game's usefulness, and actual land allocations in the Jalapa region are compared with optimal allocations under different priorities. The carrying capacity of the region is examined from this point of view, giving particular attention to the demands that increasingly urban habits of consumption may place on the land and to the role properly directed technology can play in increasing carrying capacity without causing environmental damage.

\section{INTRODUCTION}

As a consequence of recent legislation, the individual states of Mexico have been preparing plans for balanced growth which consider the diverse capabilities, needs and development of different regions within each state. Planners are giving particular emphasis to urban zones of influence and the capacity of such zones to supply food, forest products, water and other human amenities

*Present address: Environment and Policy Institute, East-West Center, Honolulu, Hawaii 96848 , U.S.A. 
to the cities within them. The approach to land-use planning described in this paper was developed during 1977 and 1978. The aims were: (1) a way to include environmental considerations together with the economic and social criteria that customarily feature in regional land-use planning; (2) an ecologically sensitive approach for the evaluation of regional carrying capacity.

The objective was to assist planners in examining the trade-offs and ecological costs of a variety of land-use objectives such as self-sufficiency in food production, production of export crops, improvement of the level and equity of rural incomes, reliable and unpolluted water supplies for agricultural and urban use, soil conservation and freedom from dependence on imported agricultural inputs such as fertilizers and pesticides. Planners could then address important questions: What is the human carrying capacity of a region (i.e., how many people can the region support on a sustained basis); and how does carrying capacity depend upon the way different land types are used?

\section{Description of the Jalapa region}

The Jalapa region was chosen for a pilot study so that methodology development could be based on a real landscape, and because the region has a geographic diversity representative of much of Mexico. The region is located in the state of Veracruz at latitude $20^{\circ} \mathrm{N}$ (Fig. 1) and is approximately $110 \mathrm{X}$ $40 \mathrm{~km}$ with 600,000 inhabitants. It extends from a $4000 \mathrm{~m}$ mountain peak to sea level at the Gulf of Mexico, embracing many different ecological environments which range from sparsely populated forest at the higher altitudes to densely settled areas of subsistence agriculture at intermediate altitudes and tropical lands at lower altitudes. The geography and natural vegetation of the region have been described by Gomez Pompa (1973).

The Jalapa region is, in many respects, a microcosm of Mexico's Gulf Zone; an area that Mexico has designated for an increase in population during the next few decades. This growth, stimulated by a petroleum boom, will undoubtedly place increasing demands on the land.

The city of Jalapa is the capital of the state of Veracruz. Salaries are its main source of wealth, generated by government offices, the state university and primary and secondary schools. As a commercial center for the surrounding countryside, it supplies personal and household goods, but the city's role as a source of monetary and technical support for agriculture is weak. Virtually no industry exists in the city, although a few factories for processing sugar and coffee are situated on the outskirts. The city's population was 200,000 in 1978 ; it has been nearly doubling every 10 years, primarily due to in-migration from rural areas. The rural population in the $4750 \mathrm{~km}^{2}$ of the Jalapa region is growing at a much slower rate.

The Jalapa region can be divided into 7 climatic zones (Table I, Fig. 2). The humid boreal zone is primarily pine and fir forests which have been decimated severely during the past 20 years by illegal logging. Deforestation and goat grazing have led to severe erosion which has removed the soil A-horizon in 


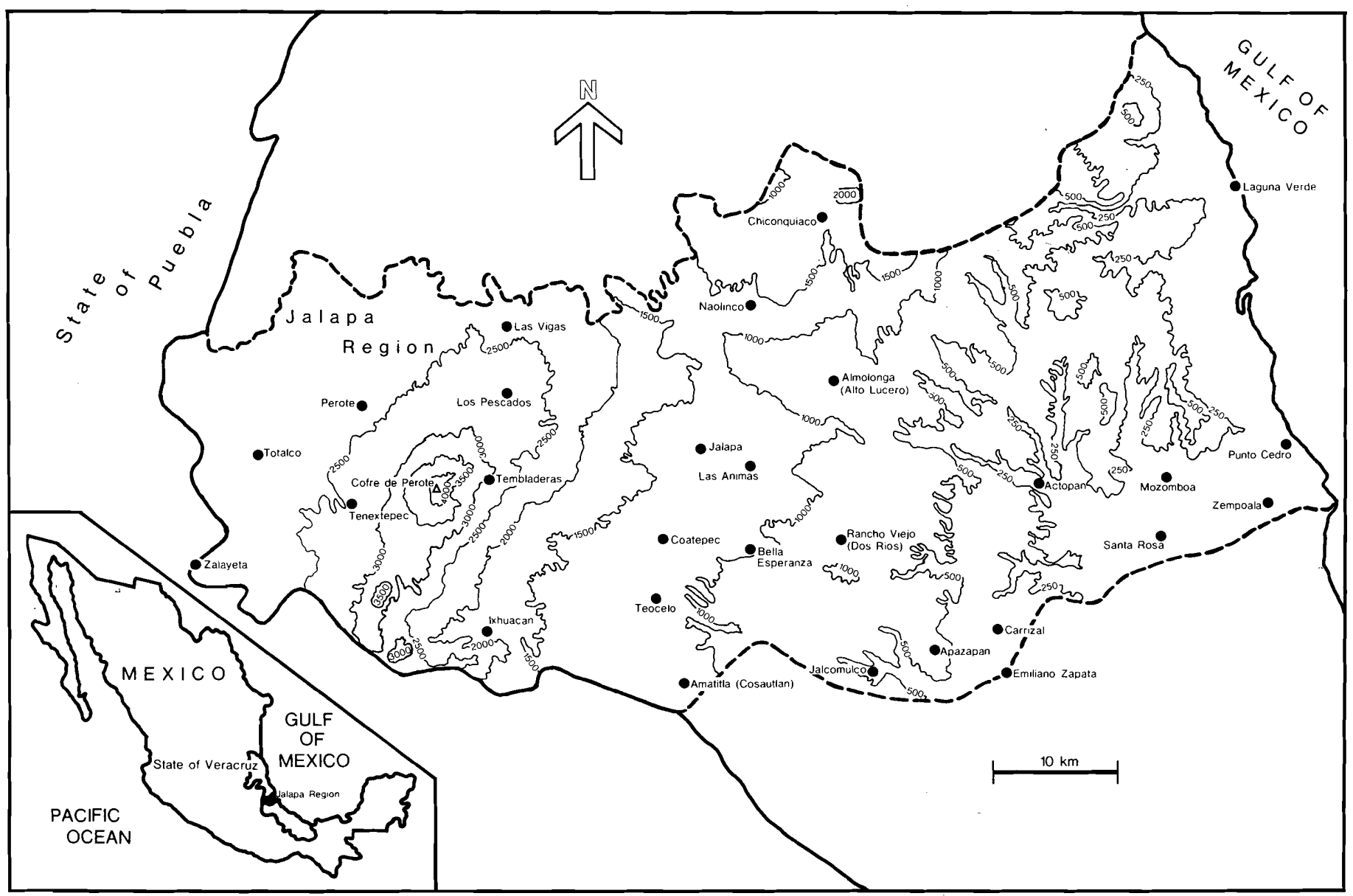

Fig. 1. Map of the Jalapa region. Dots indicate the location of weather stations which provided data for climatic zones. 


\section{TABLE I}

Climatic zones of the Jalapa region

\begin{tabular}{|c|c|c|c|c|c|c|c|c|}
\hline \multirow[t]{2}{*}{ Zone } & \multirow[t]{2}{*}{$\begin{array}{l}\text { Altitude } \\
\text { (m) }\end{array}$} & \multicolumn{2}{|c|}{$\begin{array}{l}\text { Average } \\
\text { temperature } \\
\left({ }^{\circ} \mathbf{C}\right) \\
\end{array}$} & \multirow[t]{2}{*}{$\begin{array}{l}\text { Frost- } \\
\text { free } \\
\text { months }\end{array}$} & \multirow[t]{2}{*}{$\begin{array}{l}\text { Annual } \\
\text { precipitation } \\
(\mathrm{mm})\end{array}$} & \multirow{2}{*}{$\begin{array}{l}\text { Annual } \\
\text { pan } \\
\text { evaporation } \\
(\mathrm{mm})\end{array}$} & \multirow{2}{*}{$\begin{array}{l}\text { Average } \\
\text { annual } \\
24-\mathrm{h} \\
\text { rainfall } \\
(\mathrm{mm})\end{array}$} & \multirow[t]{2}{*}{$R$-Factor ${ }^{\mathrm{c}}$} \\
\hline & & $\overline{\operatorname{Jan}^{\mathbf{a}}}$ & May $^{b}$ & & & & & \\
\hline Humid boreal & $3000-4000$ & 7 & 11 & none & 1800 & 900 & - & - \\
\hline Semiarid cool temperate & $2250-2750$ & 10 & 15 & Apr.-Sept. & 450 & 1650 & 30 & 88 \\
\hline Subhumid cool temperate & $2000-3000$ & 8 & 14 & Apr.-Sept. & 1000 & 1200 & 95 & 1080 \\
\hline Humid warm temperate & $1300-2250$ & 14 & 19 & Mar.-Oct. & 1600 & 1100 & 80 & 740 \\
\hline Humid subtropical & $900-1300$ & 16 & 22 & Mar.-Dec. & 1700 & 1200 & 65 & 471 \\
\hline Subhumid subtropical & $300-1100$ & 18 & 24 & Jan.-Dec. & 1100 & 1350 & 75 & 645 \\
\hline Subhumid tropical & $0-600$ & 22 & 29 & Jan.-Dec. & 1100 & 1650 & 85 & 850 \\
\hline
\end{tabular}

${ }^{\mathrm{a}} \mathrm{January}$ is the coldest month of the year. ${ }^{\mathrm{b}}$ May is the warmest month of the year. ${ }^{\mathrm{c}}$ Erosion $\left(\mathrm{t} \mathrm{ha}^{-1}\right.$ year $\left.^{-1}\right)$ to be expected when there is no cover, and the soil factor $(K)$ and slope factor $(L S)$ are unities; the $R$-values are based on Fig. 6 . 


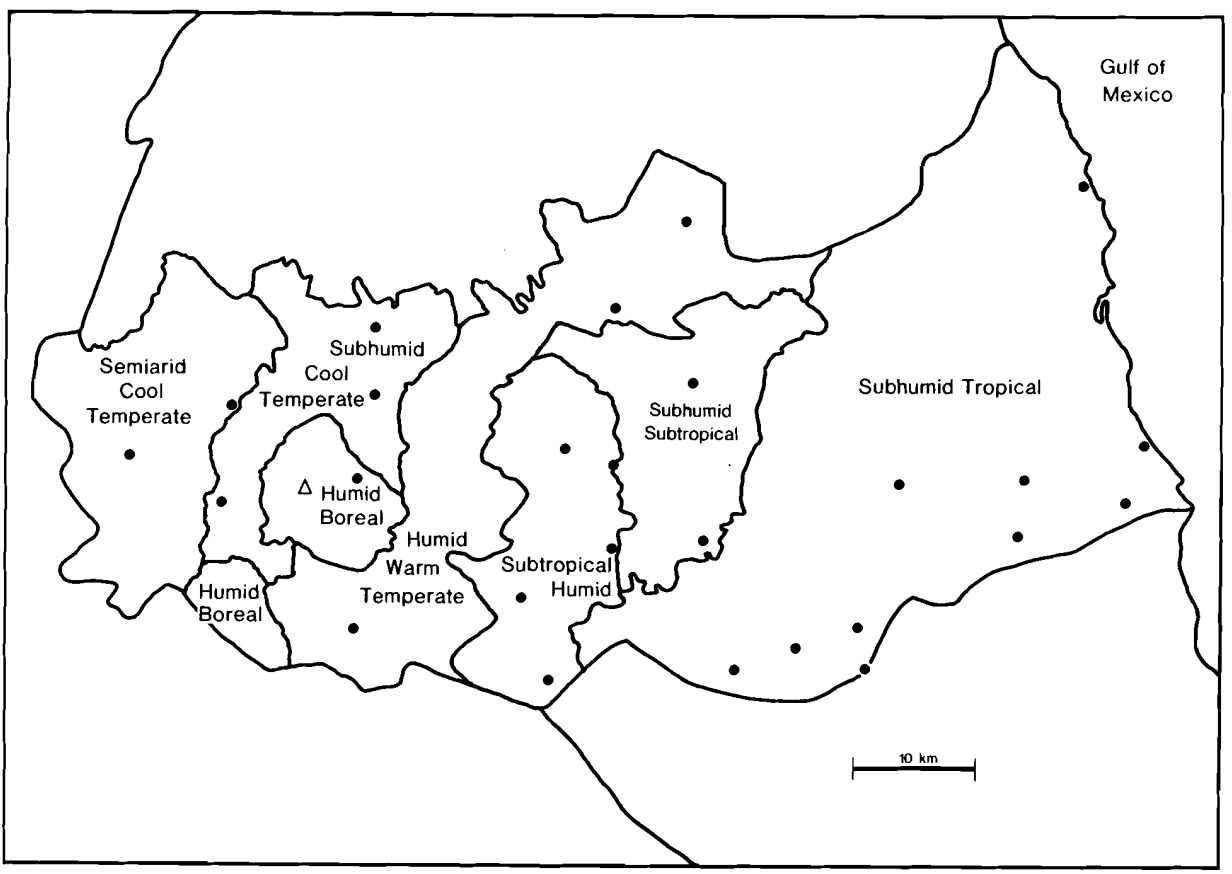

Fig. 2. Climatic zones of the Jalapa region. The dots indicate the same locations as in Fig. 1.

many areas. Where there is sufficient soil, much of the mountain is now planted with potatoes.

Below this mountainous zone, there is a semiarid, cool-temperate zone (Valley of Perote) representative of Mexico's central plateau. This zone experiences a relatively short frost-free season (April-September) and comparatively low rainfall which restrict agricultural production (Table I). Originally pine forest, this zone was in wheat production 20 years ago, but the wheat subsequently disappeared because of a rust infestation. At present, the primary crops are subsistence maize and barley which are shipped to a beer factory. Both grains yield $0.5-1 \mathrm{t} \mathrm{ha}^{-1}$ year $^{-1}$.

Descending towards the Gulf of Mexico, there is a subhumid cool-temperate zone which has subsistence maize and commercial orchards of temperate fruits such as apple, plum and pear.

Below this is the humid zone, characterized by high rainfall and deep, volcanic-ash soils which are very fertile. The city of Jalapa and most of the region's rural population are situated in this zone, primarily because of its high productivity. A mosaic of Liquidambar cloud forest, dairy pasture and subsistence maize cover the higher, warm-temperate region of the humid zone. There are also temperate fruit trees, but production is limited because many are in backyard gardens where they receive little care.

Maize produces well in the humid warm-temperate zone (an average of $2 \mathrm{t}$ $\mathrm{ha}^{-1}$ year $^{-1}$ ), but milk production is more profitable. Maize fields have given 
way to pasture as the demand for milk has increased with urbanization during the past 10 years. This change has proceeded to the extent that individuals have been able to accumulate land holdings large enough for cattle. Much of the maize still produced is used as cattle forage.

Recent, unweathered lava flows of little agricultural potential cover part of the humid warm-temperate zone. The major problem in this zone, however, is the hilly terrain where hillsides have slopes of up to $50 \%$. Erosion is conspicuous on many slopes where there is maize cultivation or overgrazing. However, soil loss, sometimes as high as $1 \mathrm{~cm}^{\text {year }}{ }^{-1}$, has not yet resulted in significant soil deterioration, because the soils are deep and a slash-burn rotation is possible in most areas. Destruction of the A-horizon might become widespread, however, if a permanent maize crop becomes common practice on the hillsides.

The lower, subtropical region of the humid zone is hilly in some places and flat in others. Coffee plantations and sugarcane predominate, interspersed with remnants of citrus orchards. Erosion is less common than in the temperate part of the humid zone because coffee trees on the hills provide adequate soil protection. Twenty years ago citrus fruits were the main crop, but a fruit-fly invasion decimated the orchards. Sugarcane has been replacing coffee as the major crop during the past decade because of low coffee prices and the provision of credit and agricultural services by sugar refineries. This trend was checked in recent years by a rise in coffee prices, but coffee prices cannot be depended upon to stay high.

The small size of landholdings, typically about $1 \mathrm{ha}$, is a problem throughout the humid zone. Many small landholders seek work elsewhere, rather than work their own land intensively, because the small scale makes it difficult to employ technology that would make the work worthwhile.

In the subhumid subtropical zone, agriculture is limited by the short rainy season. The zone has shallow soils, lava flow in some areas, hardpan in others, and is dissected by steep ravines which are of limited use. Subsistence maize and beef cattle are the main agricultural activities.

The upper part of the subhumid tropical zone has soil problems such as high alkalinity, excessive clay and poor drainage. Ravines are also a significant feature of the landscape in this zone. Papaya has become a popular commercial crop because it tolerates alkaline soils and is resistant to drought, but a virus new to the area is expected to eliminate papayas from the zone within a few years.

The lower part of the subhumid tropical zone contains basaltic hilly ridges, with shallow but productive soils, alternating with rich alluvial valleys. Rainfall during the 4-month summer rainy season is abundant and results in a highly productive 6 -month growing period, but the other 6 months are very dry. The growing season can be extended to 12 months by irrigation, resulting in 2 , or potentially 3 , crops of maize or vegetables per year. One of the alluvial valleys (Actopan) has an irrigation district of 7000 ha which is devoted to maize, rice, vegetables, tropical fruits and sugarcane, as well as some 
pasture. However, irrigation is not widespread in the subhumid tropical zone. Large beef-cattle ranches and patches of subsistence maize and vegetables occupy most of the zone.

The level of income among the rural population in the Jalapa region is generally low; most people earn U.S. $\$ 200-500$ year $^{-1}$. Farm labor wages ranged from U.S. $\$ 2.50-3.50 \mathrm{day}^{-1}$ in 1978. In contrast, owners of the larger fruit and coffee plantations and cattle ranches realize substantial profits.

Although the Jalapa region exports and imports some food, the quantities produced in the region are about the same as the quantities consumed. Food production and consumption patterns in the region include: maize, beans and vegetables produced and consumed throughout the region in rural areas which are self-sufficient in these basic foods; commercial surpluses of rice, fruits and vegetables in the tropical irrigation district; commercial production of barley and potatoes in the Perote area. Commercial surpluses are sold to the national market, and the city of Jalapa buys its vegetables, maize and other grains from the national market. Although much of the temperate fruit produced in the Jalapa region is consumed locally, a significant portion of it also enters the national market.

Milk produced in the temperate zone goes directly to Jalapa, but most of the tropical production goes to a Nestle factory. The city of Jalapa does not acquire milk from outside the region during the rainy season, but it must do so during the dry season. The Jalapa region's tropical zone is part of a coastal plain extending along the Gulf of Mexico. The coastal plain forms a single market for beef production that supplies much of Mexico, including Jalapa.

Thirty percent of the land in the region is unsuitable for any use other than forest because of steep slopes, thin soils, or inundation (Table II). However, some of this land is used for agriculture or pasture; and although the total quantity of land in use in the region is about the same as the quantity needed to supply the region's present needs, some of the uses do not correspond to the capabilities of the land and produce areas of severe erosion. The

\section{TABLE II}

Present land use in the Jalapa region ${ }^{a}$

\begin{tabular}{lccrrr}
\hline \multirow{2}{*}{ Land capability } & \multicolumn{5}{l}{ Present use } \\
\cline { 2 - 6 } & Agriculture & Pasture & Fruit & Forest $^{\mathbf{b}}$ & Total \\
\hline Any use & 850 & 199 & 149 & 433 & 1631 \\
Pasture, fruit trees, forest & 606 & 397 & 92 & 524 & 1619 \\
Forest only & 76 & 322 & 71 & 919 & 1388 \\
Total & 1532 & 918 & 312 & 1876 & $4638^{\mathrm{c}}$ \\
\hline
\end{tabular}

${ }^{a}$ All figures are based on aerial photograph interpretation, as detailed in Table XI. ${ }^{b}$ An unknown percentage of forest land is grazed by cattle, sheep, or goats. ${ }^{\mathbf{c}}$ The total land area in the Jalapa region is $4756 \mathrm{~km}^{2}$. The $118 \mathrm{~km}^{2}$ not covered by this table have other uses such as urban use or land without vegetative cover. 
problem is exacerbated by the large population in the high-rainfall, productive hilly zone and the fact that many people who cultivate subsistence maize on hillsides do not have access to flatter lands.

\section{METHODS}

\section{The land-use game}

\section{Purpose}

A land-use game was devised to examine the land-use implications of a variety of planning objectives and constraints on agricultural development resources. The game's purpose was to see how optimal allocation of many possible land-use systems among numerous land types depends on the priorities placed on conflicting planning objectives such as farm incomes, soil conservation and production quotas for different kinds of food. The game was designed to make it possible to understand the trade-offs between objectives, and, in particular, to appreciate the environmental costs of placing heavier demands on the land. With the game, it was possible to investigate how public resources (e.g., agricultural support services and irrigation works) could be allocated to ameliorate the environmental costs of increased production.

It was called a game because it was possible for the user to explore diverse combinations of objectives, priorities and available development resources, basing each new phase of the exploration on the results he had obtained so far. The game was based on optimization because this allowed the user to sift through many possible land-use patterns and focus upon those which were best for each set of objectives, priorities and development resources.

\section{Structure}

Table III shows the objectives employed in the land-use game. Additional objectives might have been employed, such as producing export crops, minimizing risks (Roumasset et al., 1979), and equalizing public investment and farm incomes throughout the region. Meat production in Table III is restricted to beef and therefore does not take account of other important sources of animal protein such as pigs and chickens. These additional goals could be explored in further development of the game.

Multi-objective optimization was achieved by means of goal programming (Lee, 1972). The decision variables $\left(x_{i j}\right)$ are square kilometers of land type $j$ allocated to land-use system $i$. The user must keep in mind that the optimal solution for the region is not simply the best use for each land type independent of other types. The optimal solution is a consequence of the joint aptitudes of all land types considered together in light of regional needs. The best solution depends on the possible uses of all land types and how the various land types help satisfy objectives and compete for limited production inputs. For example, intensive dairy farming might be the best use for humid warm-temperate hill bottoms, but an optimal solution might place maize on 


\section{TABLE III}

Planning objectives and constraints for the Jalapa region land-use game

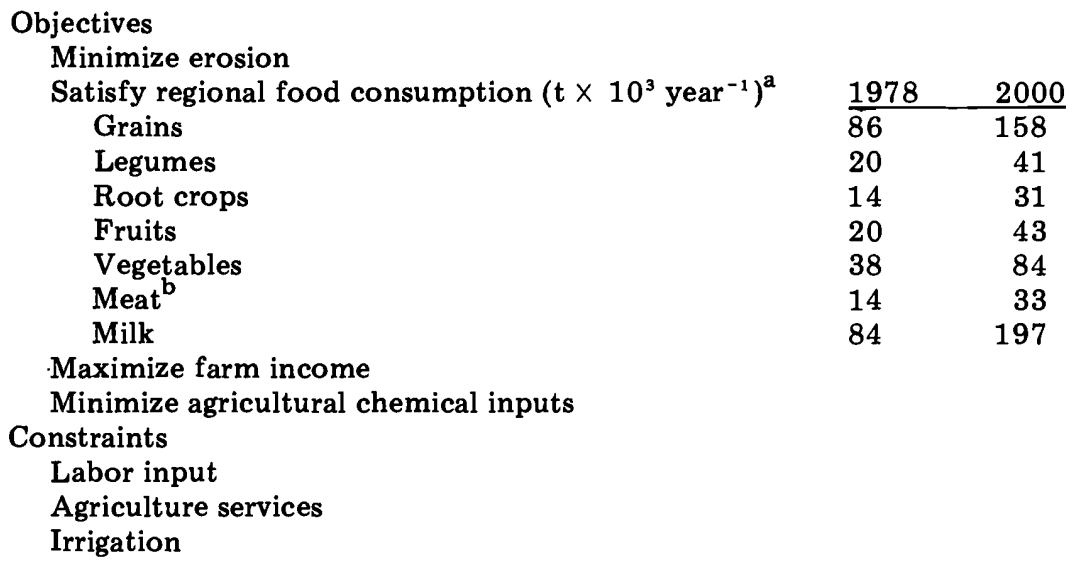

${ }^{a}$ Based upon Tables VI and VIII. ${ }^{b}$ Beef only.

the hill bottoms instead and locate dairy herds on the adjacent gentle slopes, even though slopes are inferior to hill bottoms for dairy cattle. This solution might be optimal from a regional point of view, because hill bottoms are needed to satisfy regional maize needs without causing excessive erosion.

If any one of the objectives $\left(g_{k}\right)$ in Table III is considered, the actual performance on objective $k$ for a particular allocation of land types to land uses would be

$y_{k}=\Sigma \sum_{i j} c_{i j k} x_{i j}$

where $c_{i j k}$ is the contribution (per square kilometer) to objective $k$ when land type $j$ is allocated to use $i$. This objective can be accomplished only within certain constraints (Table III): (1) $x_{i j}$ cannot be negative $\left(x_{i j} \geqslant 0\right) ;(2)$ inputs for production cannot exceed the available supply

$\sum \sum_{i j} q_{i k} x_{i j} \leqslant b_{k}$

where $q_{i k}$ is the quantity of the $k$-th production input employed when land type $j$ is allocated to land use $i$ and $b_{k}$ is the limit on the $k$-th production input; and (3) the total amount of each land type allocated to different uses cannot exceed the total amount of that land type available

$\sum_{i} x_{i j} \leqslant a_{j}$

where $a_{j}$ is the number of square kilometers of land type $j$. 
The purpose of the optimization is to satisfy the objectives $\left(g_{k}\right)$ insofar as possible; that is, to find those values of $x_{i j}$ which minimize the deviations between the objectives and the values that are actually realized. Expressed as the minimum of the sum of absolute values of deviations, this optimization is $\min \left[\sum_{k} w_{k} \operatorname{Abs}\left(y_{k}-g_{k}\right)\right]$

where $w_{k}$ is the weighting value for the $k$-th objective.

The contributions $\left(c_{i j k}\right)$ of each combination of land type and land-use system to each objective, the inputs required by each land-use system $\left(q_{i k}\right)$, and the surface area $\left(a_{j}\right)$ of each land type available for allocation to different land-use systems were all built into the game. The user could change any of these if he questioned their correctness, but they were usually left constant. With every new optimization run, however, the user had to specify goal levels $\left(g_{k}\right)$ for the objectives, priorities for the objectives, and values for constraints on production inputs $\left(b_{k}\right)$. Each unique combination of objectives and constraints formed a scenario; by formulating different scenarios and observing the optimum land allocation $\left(x_{i j}\right)$ and optimal performance $\left(y_{k}\right)$ for the objectives of each scenario, the user explored trade-offs among planning objectives and came to appreciate the environmental implications of different planning priorities and different production inputs.

\section{Computer format}

The computer program to implement the land-use game is based upon a computer routine for goal programming written by Bartlett et al. (1976) and is available upon request. It first prints a summary of the objectives, priorities and constraints that define a particular scenario, i.e., the inputs for a particular computer run. (1) Goals $\left(g_{k}\right)$ for food production, erosion, income, etc., and the priority of each. (2) Constraints $\left(b_{k}\right)$ on production inputs (agricultural support service, irrigation, labor). (3) Total number of square kilometers $\left(a_{j}\right)$ of each land type. The program then prints the optimization results that constitute the output from the computer run. (1) Number of square kilometers $\left(x_{i j}\right)$ of each land type allocated to each land-use system in the optimum solution. (2) A report on whether each objective was achieved, giving the performance for each objective $\left(y_{k}\right)$ (e.g., the amount of food produced, erosion and income generated). (3) A report on utilization of production inputs relative to constraints (e.g., agricultural services utilized, area irrigated and labor employed).

\section{Data base}

The land-use game was built around the idea of land types and land-use systems. The description of the Jalapa region, therefore, was similarly structured. The following sections describe the procedures used to estimate the coefficients $\left(a_{j}, c_{i j k}\right.$, and $\left.q_{i k}\right)$ built into the game. Specifically, it was re- 
quired to: (1) identify functionally discrete land types unique as to climate, soil and topography (the performance of each land type differing under the various land-use systems); (2) identify discrete land-use systems; (3) catalog the expected performance of each land type under each land-use system for (a) erosion (b) production (c) sustainability; (4) catalog the inputs required and income generated by each land-use system; (5) inventory the number of square kilometers of each land type in the Jalapa region.

\section{Land type classification}

A landscape approach (Christian and Stewart, 1968) based on land form was used for identifying land types because: (1) land form correlates highly with suitability for different land uses; (2) land types based on land form can be inventoried with aerial photographs, thereby minimizing costly field surveys.

The classification was spatially "fine grained" and could account for changes in use suitability within a distance of $100 \mathrm{~m}$. An area of rolling hills, for example, could be assigned 3 land types based on topography: hill tops, hillsides and hill bottoms.

The land classification system was hierarchical with 3 levels: (1) climatic zones (Fig. 2); (2) geomorphological systems (see Fig. 4); and (3) topographic elements (see Fig. 5). Each level was defined and inventoried on the basis of satellite images or aerial photographs and the data supplemented with field information (e.g., weather data, interviews, vegetation sampling and soil analyses).

The region was divided into 7 climatic zones (Table I), each of which contained one or more geomorphological systems determined by land form. Each geomorphological system had a characteristic pattern of relief, with the same topographic features, such as hill tops, hillsides and hill bottoms interdigitated throughout the geomorphological system. Each topographic unit represented a unique land type as to climate, soil and topography. Details of the land classification for the Jalapa region are given by Sancholuz et al. (1981).

Climatic zones. Climatic zones (Fig. 2) were named as in Holdridge (1971). Initial identification of the zones was based on false-color LANDSAT satellite images at a scale of 1:250,000. The colors in a false-color image result from light reflecting from the earth's surface in three spectral bands. Although the reflection depends in part on the soil, it is influenced primarily by vegetation, both plant form (physiognomy) and plant physiology (especially water status). Different zones were readily discernable on false-color images of the Jalapa region, each zone a mosaic of the same colors, texture and tone. Statistical analyses of temperature and precipitation records from 48 weather stations in the Jalapa region provided confirmation that the vegetation-mosaic zones on the satellite images were in fact a reflection of climate (Koterba and Lavin, 1979). The typical annual pattern of precipitation and evapotranspiration for each climatic zone is shown in Fig. 3. 

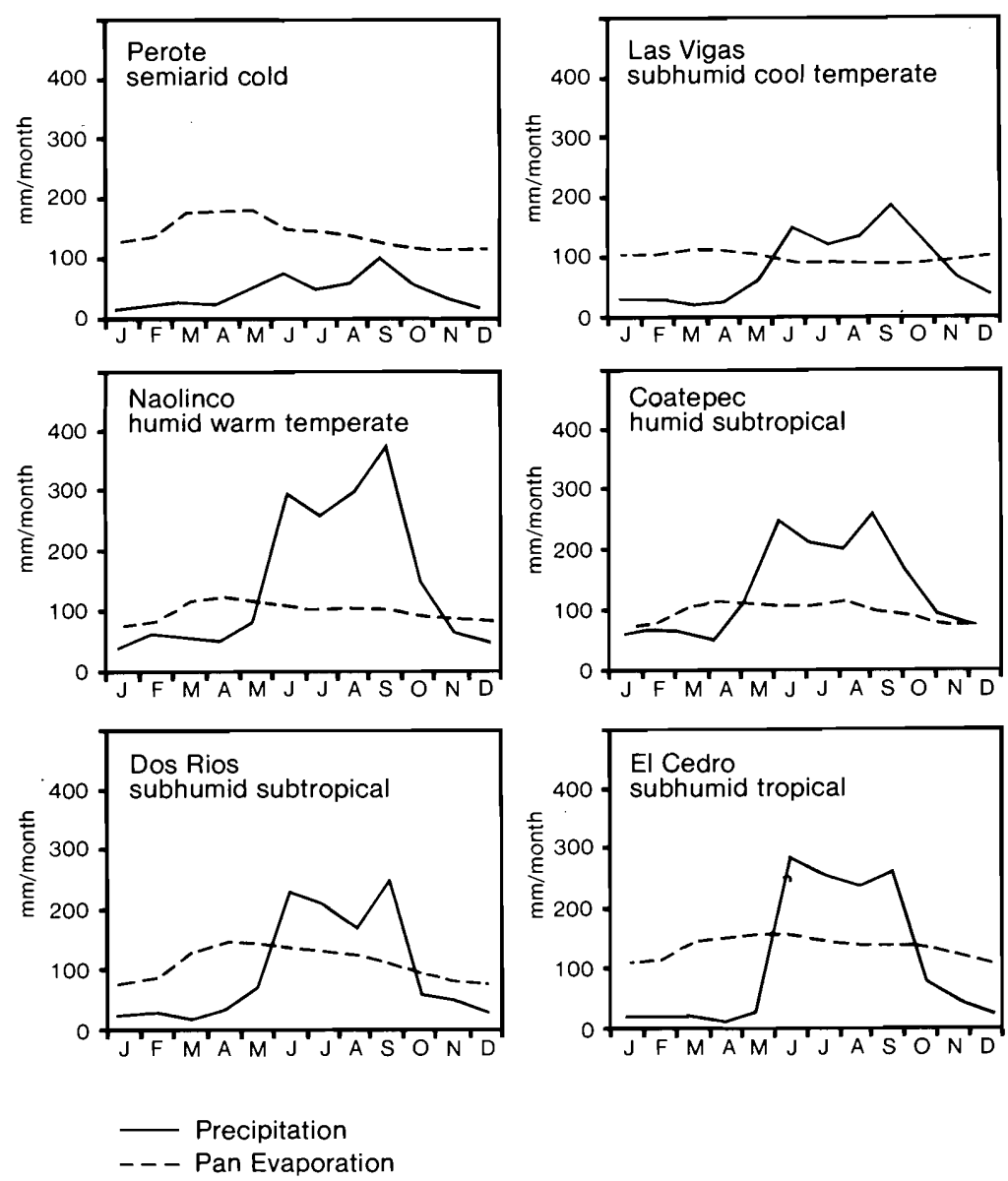

Fig. 3. Seasonal patterns of precipitation and pan evaporation in the climatic zones of the Jalapa region.

Geomorphological systems. A black and white aerial photomosaic of the region (scale 1:100,000) was used to delineate geomorphological systems (Sancholuz et al., 1981). Each geomorphological system on the photomosaic had a characteristic texture, tone and pattern that indicated a corresponding landform on the ground, that is, a recurring pattern of topography and soil.

Thirteen geomorphological systems were identified (1-4 systems in each climatic zone, Fig. 4). When a climatic zone contained more than one geomorphological system, the systems often differed not only in land form but also in soils. Field surveys showed that, aside from recent alluvial deposits, each system was derived from a single parent material and usually (but not always) consisted of soils of the same age and general profile that corresponded to major soil groups of the FAO/UNESCO soil classification system. 


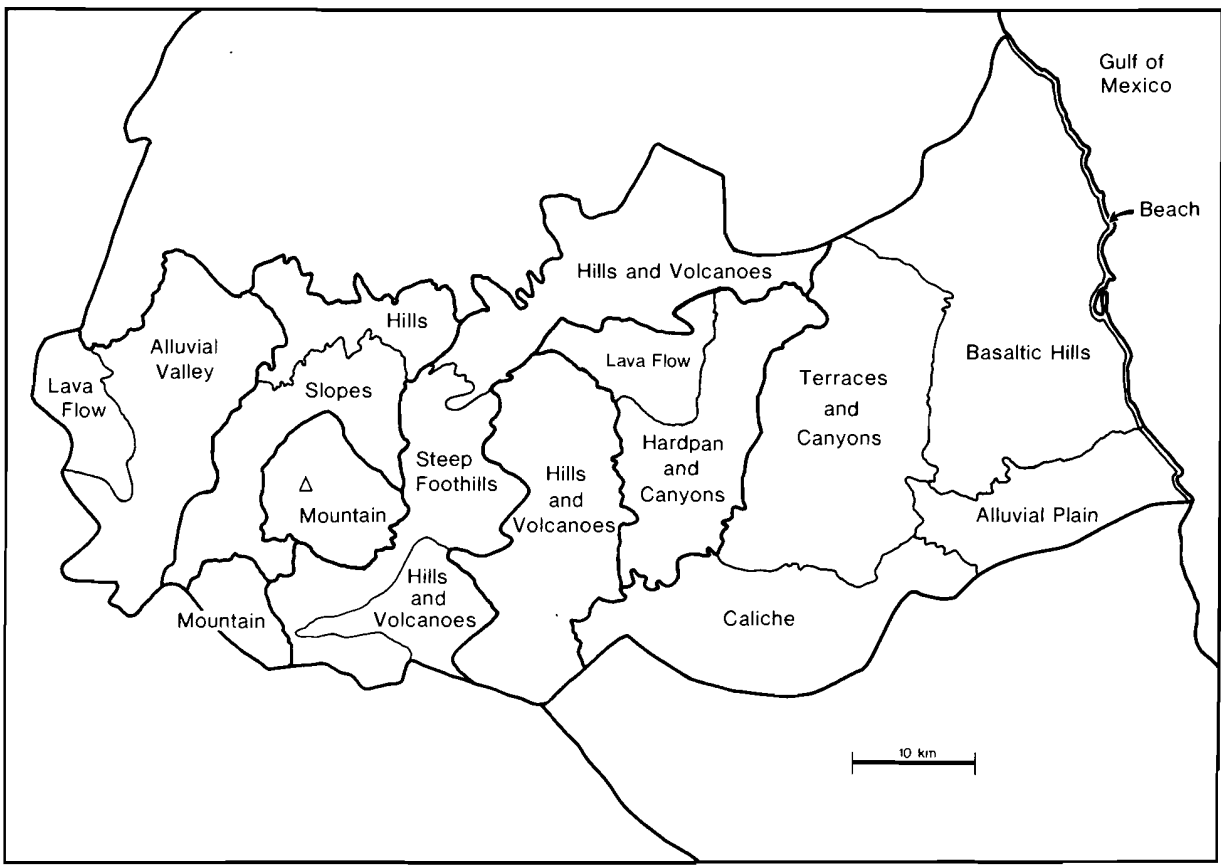

Fig. 4. Geomorphological zones of the Jalapa region. Thick lines indicate boundaries between climatic zones.
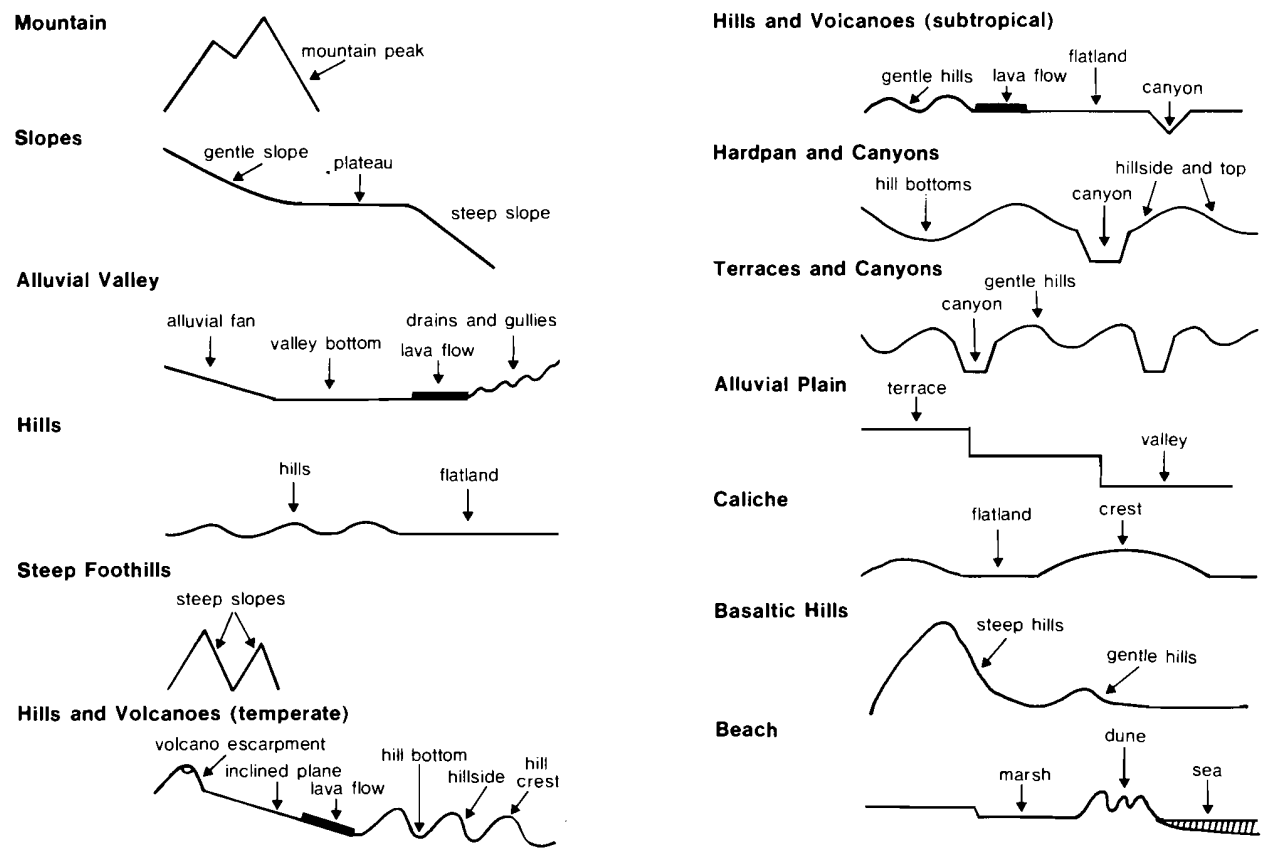

Fig. 5. Topographic profiles showing land types in each of the geomorphological zones. Each land type is repeated numerous times throughout the zone. 
TABLE IV

Land types in the Jalapa region

\begin{tabular}{|c|c|c|c|c|c|}
\hline Climatic zone & $\begin{array}{l}\text { Geomorphological } \\
\text { zone }\end{array}$ & $\begin{array}{l}\text { Topographic } \\
\text { element }\end{array}$ & Soil type $e^{b}$ & $\begin{array}{l}\text { Surface } \\
\text { area }\left(\mathrm{km}^{2}\right)\end{array}$ & \\
\hline Humid boreal & Mountain & Mountain peak & Lithosol & 210 & \\
\hline \multirow[t]{2}{*}{$\begin{array}{l}\text { Semiarid cool } \\
\text { temperate }\end{array}$} & Slopes & $\begin{array}{l}\text { Gentle slope } \\
\text { Plateau } \\
\text { Steep slopes }\end{array}$ & $\begin{array}{l}\text { Regosol (A) } \\
\text { Regosol (A) } \\
\text { Regosol (A) }\end{array}$ & $\begin{array}{r}123 \\
30 \\
188\end{array}$ & \\
\hline & Alluvial valley & $\begin{array}{l}\text { Alluvial fans } \\
\text { Valley bottom } \\
\text { Drains and gullies } \\
\text { Lava flow }\end{array}$ & $\begin{array}{l}\text { Luvisol } \\
\text { Luvisol } \\
\text { Luvisol } \\
\text { Lithosol }\end{array}$ & $\begin{array}{r}131 \\
151 \\
96 \\
119\end{array}$ & \\
\hline $\begin{array}{l}\text { Subhumid cool } \\
\text { temperate }\end{array}$ & Hills & $\begin{array}{l}\text { Hills } \\
\text { Flatland }\end{array}$ & $\begin{array}{l}\text { Regosol (B) } \\
\text { Regosol (B) }\end{array}$ & $\begin{array}{l}150 \\
104\end{array}$ & \\
\hline Humid & Steep Foothills & Steep slopes & Latosol & 338 & \\
\hline warm temperate & Hills \& volcanoes & $\begin{array}{l}\text { Volcano escarpments } \\
\text { Hill bottoms } \\
\text { Hillsides } \\
\text { Hill crests } \\
\text { Inclined plane } \\
\text { Lava flow }\end{array}$ & $\begin{array}{l}\text { Latosol } \\
\text { Latosol } \\
\text { Latosol } \\
\text { Latosol } \\
\text { Andosol } \\
\text { Lithosol }\end{array}$ & $\begin{array}{r}26 \\
58 \\
100 \\
72 \\
77 \\
36\end{array}$ & \\
\hline $\begin{array}{l}\text { Humid } \\
\text { subtropical }\end{array}$ & Hills and volcanoes & $\begin{array}{l}\text { Lava flow } \\
\text { Canyons } \\
\text { Gentle hills } \\
\text { Flatland }\end{array}$ & $\begin{array}{l}\text { Lithosol } \\
\text { Lithosol } \\
\text { Latosol } \\
\text { Latosol }\end{array}$ & $\begin{array}{r}79 \\
100 \\
126 \\
168\end{array}$ & \\
\hline $\begin{array}{l}\text { Subhumid } \\
\text { subtropical }\end{array}$ & $\begin{array}{l}\text { Hardpan and can- } \\
\text { yons }\end{array}$ & $\begin{array}{l}\text { Hill bottoms } \\
\text { Hillsides and tops } \\
\text { Canyons }\end{array}$ & $\begin{array}{l}\text { Hardpan } \\
\text { Hardpan } \\
\text { Hardpan }\end{array}$ & $\begin{array}{r}32 \\
154 \\
26\end{array}$ & \\
\hline \multirow[t]{5}{*}{$\begin{array}{l}\text { Subhumid } \\
\text { tropical }\end{array}$} & $\begin{array}{l}\text { Terraces and } \\
\text { canyons }\end{array}$ & $\begin{array}{l}\text { Canyons } \\
\text { Gentle hills }\end{array}$ & $\begin{array}{l}\text { Luvisol } \\
\text { Luvisol }\end{array}$ & $\begin{array}{l}412 \\
285\end{array}$ & \\
\hline & Alluvial plain & Terraces and valleys & Luvisol & 431 & \\
\hline & Caliche & $\begin{array}{l}\text { Crests } \\
\text { Flatland }\end{array}$ & $\begin{array}{l}\text { Rendzina } \\
\text { Rendzina }\end{array}$ & $\begin{array}{r}154 \\
98\end{array}$ & \\
\hline & Basaltic hills & $\begin{array}{l}\text { Steep hills } \\
\text { Gentle hills }\end{array}$ & $\begin{array}{l}\text { Planosol } \\
\text { Planosol }\end{array}$ & $\begin{array}{l}276 \\
283\end{array}$ & \\
\hline & Beach & $\begin{array}{l}\text { Dunes } \\
\text { Marsh }\end{array}$ & $\begin{array}{l}\text { Arenosol } \\
\text { Gleysol }\end{array}$ & $\begin{array}{l}70 \\
53\end{array}$ & \\
\hline
\end{tabular}

${ }^{a}$ Shown in Fig. 5. ${ }^{b}$ Described in Table V.

Topographic elements. On the basis of black and white aerial photographs (scale 1:50,000) examined under a stereoscope, a typical profile was drawn for each geomorphological system. Each profile (Fig. 5) contained up to 6 topographic elements based on slope and curvature (convex, plane, concave). Each topographic element in each geomorphological system represented a unique land type. Thirty-three land types were identified in the Jalapa region for use in the land-use game (Table IV). 


\begin{tabular}{|c|c|c|c|c|c|c|c|}
\hline \multirow{2}{*}{. } & \multicolumn{2}{|c|}{ Productivity } & \multirow{2}{*}{$\begin{array}{l}\text { Average } \\
\text { slope (\%) }\end{array}$} & \multirow[t]{2}{*}{ Texture } & \multirow{2}{*}{$\begin{array}{l}\left.\text { Erodibility }(e)_{j}\right) \\
\left(\text { t ha }^{-1} \text { year }^{-1}\right)\end{array}$} & \multirow{2}{*}{$\begin{array}{l}\text { Average } \\
\text { soil depth } \\
\text { (m) }\end{array}$} & \\
\hline & Rainfed & Irrigated & & & & & \\
\hline & - & - & $>50$ & - & $>\mathbf{2 0 0 0}$ & 0.4 & \\
\hline & $\begin{array}{l}0.45 \\
0.30 \\
0.41\end{array}$ & $\begin{array}{l}1.08 \\
0.72 \\
0.62\end{array}$ & $\begin{array}{r}17 \\
1 \\
40\end{array}$ & $\begin{array}{l}\text { Loamy sand } \\
\text { Sandy loam } \\
\text { Sandy loam }\end{array}$ & $\begin{array}{r}25 \\
2 \\
2000\end{array}$ & $\begin{array}{l}1.2 \\
1.1 \\
1.3\end{array}$ & \\
\hline & $\begin{array}{l}0.43 \\
0.57 \\
0.25 \\
0.30\end{array}$ & $\begin{array}{l}1.03 \\
1.37 \\
0.60 \\
0.72\end{array}$ & $\begin{array}{r}10 \\
4 \\
17 \\
10\end{array}$ & $\begin{array}{l}\text { Sandy loam } \\
\text { Loamy sand } \\
\text { Sandy loam } \\
\text { Loamy sand }\end{array}$ & $\begin{array}{r}16 \\
4 \\
50 \\
4\end{array}$ & $\begin{array}{l}1.4 \\
1.9 \\
0.7 \\
0.7\end{array}$ & \\
\hline & $\begin{array}{l}0.50 \\
0.50\end{array}$ & $\begin{array}{l}0.75 \\
0.75\end{array}$ & $\begin{array}{l}11 \\
10\end{array}$ & $\begin{array}{l}\text { Loam } \\
\text { Sandy loam }\end{array}$ & $\begin{array}{l}170 \\
170\end{array}$ & $\begin{array}{l}1.3 \\
1.9\end{array}$ & \\
\hline & 0.59 & 0.71 & 50 & Loam & 1300 & 1.5 & \\
\hline & $\begin{array}{l}0.82 \\
0.81 \\
0.73 \\
0.73 \\
0.82 \\
0.54\end{array}$ & $\begin{array}{l}1.07 \\
1.05 \\
0.95 \\
0.95 \\
0.98 \\
0.70\end{array}$ & $\begin{array}{r}50 \\
6 \\
31 \\
12 \\
15 \\
15\end{array}$ & $\begin{array}{l}\text { Loam } \\
\text { Loam } \\
\text { Loam } \\
\text { Loam } \\
\text { Loam } \\
\text { Sandy loam }\end{array}$ & $\begin{array}{r}1300 \\
47 \\
590 \\
125 \\
185 \\
185\end{array}$ & $\begin{array}{l}1.5 \\
1.5 \\
1.5 \\
1.2 \\
1.1 \\
0.3\end{array}$ & \\
\hline & $\begin{array}{l}0.90 \\
0.39 \\
0.70 \\
0.70\end{array}$ & $\begin{array}{l}1.26 \\
0.55 \\
0.98 \\
0.98\end{array}$ & $\begin{array}{r}15 \\
37 \\
30 \\
2\end{array}$ & $\begin{array}{l}\text { Sandy loam } \\
\text { Sandy loam } \\
\text { Sandy loam } \\
\text { Sandy loam }\end{array}$ & $\begin{array}{r}150 \\
500 \\
300 \\
9\end{array}$ & $\begin{array}{l}0.3 \\
1.0 \\
1.2 \\
1.0\end{array}$ & \\
\hline & $\begin{array}{l}0.82 \\
0.56 \\
0.40\end{array}$ & $\begin{array}{l}1.48 \\
1.01 \\
0.72\end{array}$ & $\begin{array}{r}3 \\
7 \\
26\end{array}$ & $\begin{array}{l}\text { Loamy clay } \\
\text { Sandy } \\
\text { Loam }\end{array}$ & $\begin{array}{r}20 \\
70 \\
300\end{array}$ & $\begin{array}{l}0.5 \\
0.5 \\
0.3\end{array}$ & ' \\
\hline & $\begin{array}{l}0.88 \\
1.00\end{array}$ & $\begin{array}{l}2.46 \\
2.80\end{array}$ & $\begin{array}{r}37 \\
6\end{array}$ & $\begin{array}{l}\text { Loamy clay } \\
\text { Sandy loam }\end{array}$ & $\begin{array}{r}610 \\
36\end{array}$ & $\begin{array}{l}0.3 \\
0.4\end{array}$ & \\
\hline & 1.00 & 2.80 & 2 & Loam & 16 & 1.3 & \\
\hline & $\begin{array}{l}0.64 \\
0.64\end{array}$ & $\begin{array}{l}1.66 \\
1.66\end{array}$ & $\begin{array}{l}\mathbf{5} \\
\mathbf{2}\end{array}$ & $\begin{array}{l}\text { Loam } \\
\text { Clay }\end{array}$ & $\begin{array}{r}25 \\
9\end{array}$ & $\begin{array}{l}0.3 \\
0.7\end{array}$ & \\
\hline & $\begin{array}{l}0.59 \\
1.00\end{array}$ & $\begin{array}{l}1.65 \\
2.80\end{array}$ & $\begin{array}{l}41 \\
12\end{array}$ & $\begin{array}{l}\text { Loamy clay } \\
\text { Loam }\end{array}$ & $\begin{array}{l}850 \\
150\end{array}$ & $\begin{array}{l}0.4 \\
0.7\end{array}$ & \\
\hline & $\begin{array}{l}0.43 \\
0.33\end{array}$ & $\begin{array}{l}1.20 \\
2.32\end{array}$ & $\begin{array}{r}5 \\
10\end{array}$ & $\begin{array}{l}\text { Loam } \\
\text { Sand }\end{array}$ & $\begin{array}{l}45 \\
45\end{array}$ & $\begin{array}{l}2.0 \\
1.2 \\
\end{array}$ & \\
\hline
\end{tabular}

\section{Land-use systems}

A land-use system was defined by (1) the crop or crop group produced and (2) the technology employed. A crop group contained crops that behave similarly. For example, apples, plums and pears were designated as "temperate fruits". A crop group could also specify two or more crops interdigitated spatially in the same field (e.g., maize and beans) or interdigitated seasonally on the same field (e.g., maize in the summer and vegetables in the winter in the tropical zone). 
TABLE V

Major soil types in the Jalapa region

\begin{tabular}{|c|c|c|c|c|c|c|c|}
\hline $\begin{array}{l}\text { Soil } \\
\text { type }^{a}\end{array}$ & Family $^{b}$ & $\begin{array}{l}\text { Parent } \\
\text { material }\end{array}$ & $\begin{array}{l}\text { Average } \\
\text { organic } \\
\text { matter (\%) }\end{array}$ & $\begin{array}{l}\text { Average } \\
\text { pH }\end{array}$ & $\begin{array}{l}\text { Cation } \\
\text { exchange } \\
\text { capacityc } \\
\left(\mathrm{Eq} \mathrm{m}^{-2}\right) \\
\end{array}$ & $\begin{array}{l}\text { Nitrogen } \\
\left(\mathrm{g} \mathrm{m}^{-2}\right)\end{array}$ & - \\
\hline Regosol (A) & & $\begin{array}{l}\text { Volcanic } \\
\text { cinder and } \\
\text { ash }\end{array}$ & 2 & 6.5 & 67 & 210 & \\
\hline Luvisol & & $\begin{array}{l}\text { Alluvium } \\
\text { (volcanic ash) }\end{array}$ & 2 & 7.2 & 92 & 290 & \\
\hline Regosol (B) & $\begin{array}{l}\text { Xeric } \\
\text { eutrandept }\end{array}$ & Volcanic ash & 5 & 6.3 & 140 & 600 & \\
\hline Litosol & & Lava & 0.2 & 6.2 & - & - & \\
\hline Andosol & $\begin{array}{l}\text { Typic } \\
\text { hydrandept }\end{array}$ & Volcanic ash & 10 & 6.0 & 220 & 3500 & \\
\hline Latosol & $\begin{array}{l}\text { Typic } \\
\text { eutrandept }\end{array}$ & Volcanic ash & 8 & 5.7 & 160 & 1100 & . \\
\hline Hardpan & $\begin{array}{l}\text { Oxic } \\
\text { ustropept }\end{array}$ & $\begin{array}{l}\text { Consolidated } \\
\text { silica, } \\
\text { volcanic ash }\end{array}$ & 2 & 5.6 & 170 & 470 & \\
\hline Rendzina & & Calcareous & 4 & 7.6 & 42 & 150 & \\
\hline Luvisol & $\begin{array}{l}\text { Typic } \\
\text { ustifluvent }\end{array}$ & $\begin{array}{l}\text { Alluvium } \\
\text { (primarily } \\
\text { calcareous) }\end{array}$ & 4 & 7.0 & 290 & 1200 & \\
\hline Planosol & $\begin{array}{l}\text { Typic } \\
\text { ustropept }\end{array}$ & Basalt & 5 & 6.3 & 350 & 1200 & \\
\hline Arenosol & & $\begin{array}{l}\text { Calcareous } \\
\text { and sand } \\
\text { deposits }\end{array}$ & 2 & 7.2 & 115 & 310 & \\
\hline
\end{tabular}

The technology of production was evaluated first by the level of technology: "prevailing technology", i.e., the inputs and practices actually employed by most farmers in the region; or "modern technology", the inputs and practices recommended by the appropriate agricultural experiment station. Modern technology was usually characterized by heavier and technically more-precise use of agricultural chemicals compared to prevailing technology; modern technology might or might not involve mechanization and in fact often required greater labor inputs than prevailing technology. We have documented the occurrence of these two discrete cultivation technologies in coffee plantations (Marten and Sancholuz, 1981a), and the same distinction holds for other crops as well. 


$\begin{array}{llll}\begin{array}{l}\text { Phosphorous c } \\ \left.(\mathrm{mg} \mathrm{m})^{-2}\right)\end{array} & \begin{array}{l}\text { Potassium } \\ \left(E^{-2} \mathrm{~m}^{-2}\right)\end{array} & \begin{array}{l}\text { Calcium } \\ \left(\mathrm{Eq} \mathrm{m}^{-2}\right)\end{array} & \begin{array}{l}\text { Magnesium } \\ \left(\mathrm{Eq} \mathrm{m}^{-2}\right)\end{array}\end{array}$ Problems

\begin{tabular}{|c|c|c|c|c|}
\hline 2 & 3.4 & 28 & 4 & $\begin{array}{l}\text { Eroded, deficiency } \\
\text { of base elements }\end{array}$ \\
\hline 550 & 7.7 & 71 & 9 & $\begin{array}{l}\text { Low organic matter, } \\
\text { wind erosion }\end{array}$ \\
\hline 15 & 9.3 & 59 & 8 & $\begin{array}{l}\text { Generally low in } \\
\text { major nutrients }\end{array}$ \\
\hline- & - & - & - & $\begin{array}{l}\text { Shallow, nitrogen } \\
\text { deficiency }\end{array}$ \\
\hline 20 & 10.3 & 48 & 7 & \\
\hline 1 & 1.4 & 12 & 13 & $\begin{array}{l}\text { Phosphorous fixation, } \\
\text { possible aluminum or } \\
\text { manganese toxicity, } \\
\text { possible calcium and } \\
\text { potassium deficiency }\end{array}$ \\
\hline 11 & 1.3 & 32 & 47 & $\begin{array}{l}\text { Shallow, phosphorous } \\
\text { deficiency }\end{array}$ \\
\hline 8 & 0.4 & 38 & 2 & $\begin{array}{l}\text { High pH, poor drain- } \\
\text { age, possible iron } \\
\text { deficiency }\end{array}$ \\
\hline 1400 & 10.6 & 620 & 39 & \\
\hline 300 & 6.1 & 180 & 48 & $\begin{array}{l}\text { Poor drainage, shallow } \\
\text { possible iron or aluminum } \\
\text { toxicity }\end{array}$ \\
\hline 950 & 5.5 & 870 & 13 & Excessive drainage \\
\hline
\end{tabular}

based on a single representative soil pit for each soil type, analyses described by Zinke (1981).

The second technology criterion was the presence or absence of irrigation, so 4 technology combinations could be applied to each crop group to define different land-use systems: (1) prevailing technology, rainfed; (2) prevailing technology, irrigated; (3) modern technology, rainfed; (4) modern technology, irrigated. The "prevailing technology, irrigated" combination is not often to be expected in practice. Irrigation is expensive and would logically be accompanied by modern technology.

\section{Estimation of erosion}

Because one objective of the Jalapa regional planning project was to minimize soil erosion, the erosion resulting from each land use on each land type 
was estimated. Erosion evaluations served also as indicators for water management. Less erosion would be associated with less runoff and a cleaner, more even flow of water throughout the year.

The Universal Soil-Loss Equation (Wischmeier and Smith, 1965) was used to predict erosion, i.e., the annual soil loss in tons per hectare. It was assumed that the erosion that would occur on a particular land type with a particular land use was the product of the erosivity $E_{i}$ of the land use and the erodibility $e_{j}$ of the land type. Erosion $=E_{i} e_{j}$, where $E_{i}$ is the erosion that occurs under land use $i$ compared with bare ground; $e_{j}$ is the erosion that would occur on land type $j$ if there were bare ground.

The erosivity $\left(E_{i}\right)$ of a land-use system is the product of a crop factor (C) and a conservation practice factor $(\mathrm{P})$ in the notation of the Universal SoilLoss Equation. To compare the different land-use systems independent of any special soil conservation measure which might be applied, the erosivity values were based exclusively on the crop factors for each land-use system, assuming conservation practice factors to have a constant value of 1 .

Crop factors indicate the extent to which erosion is reduced by the presence of a vegetative cover. Crop factors have been evaluated for a variety of agricultural cropping systems (Wischmeier and Smith, 1965) and nonagricultural vegetation cover types (Wischmeier, 1975). Crop factors from these sources were used, as well as unpublished U.S. Soil Conservation Service crop factors for Puerto Rican crops. With bare ground as a reference $(C=1)$, crop factors are typically in the range of $0.30-0.50$ for annual crops where soil is exposured during cultivation, but can be as little as 0.003 for an undisturbed forest. (See Table $\mathrm{X}$ for typical erosivity values estimated for land-use systems in the Jalapa region.)

The equation for estimating the erodibility of a land type (Table IV) is $e_{j}=R K L S . R$ is the rainfall factor, the erosive force caused by the impact of raindrops on the soil surface. An approximation for estimating $R$ was used (Fig. 6) based on the maximum 6-h rainfall in 2 years (Wischmeier, 1974). Maximum rainfall is a better predictor of erosion than total annual rainfall because nearly all the erosion in a year occurs during the heaviest storms. As 6-h maximum rainfall statistics were not available for weather stations in the Jalapa region, 24-h maximum rainfall was used. Error caused by this substitution was insignificant as the heaviest rainstorms seldom last more than a few hours; the maxima for 6 and $24 \mathrm{~h}$ are therefore nearly the same. Maximum 24-h rainfalls and rainfall factors for the climatic zones in the Jalapa region are shown in Table I.

$K$ is the soil factor, which depends upon soil texture, organic matter and permeability (Wischmeier and Mannering, 1969). Particularly important is organic matter, which determines the crumb structure that protects soil particles from breaking loose under impact from raindrops striking the soil surface. Soil factors were estimated by means of the nomograph of Wischmeier et al. (1971).

$L$ is the slope-length factor. Slope length is the distance from the point of 


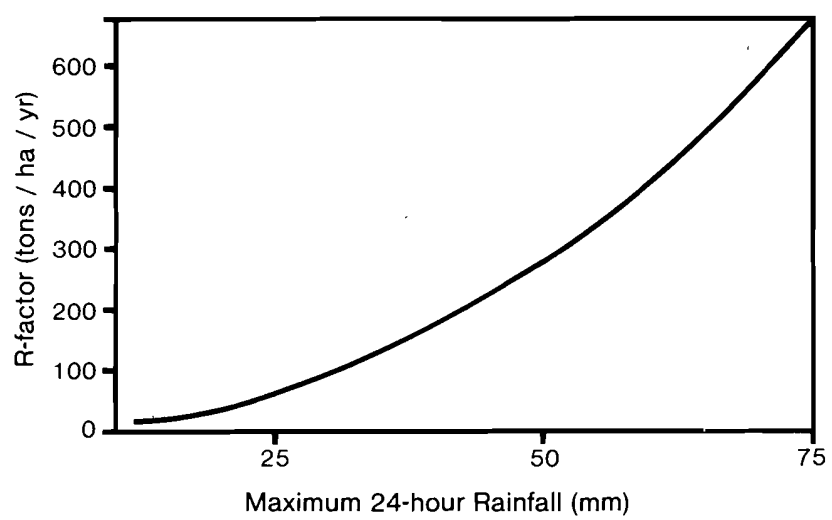

Fig. 6. Relationship of the rainfall erodibility factor $(R)$ to maximum 24 -h rainfall in a year (Wischmeier, 1974).

origin of overland flow to the point where sediment deposition begins or runoff enters a drainage channel. Erosion increases with slope length, because the capacity of water to transport soil increases as the runoff accumulates while flowing down a hill.

$S$ is the slope-gradient factor, which can have an enormous effect on erodibility. Figure 7 shows the value of the product $L S$ as a function of slope length and slope gradient. $L S$ values in Fig. 7 apply only to uniform slopes: a concave slope will have less erosion and a convex slope will have more erosion. This was corrected for by using the weighted slope of Wischmeier (1974).

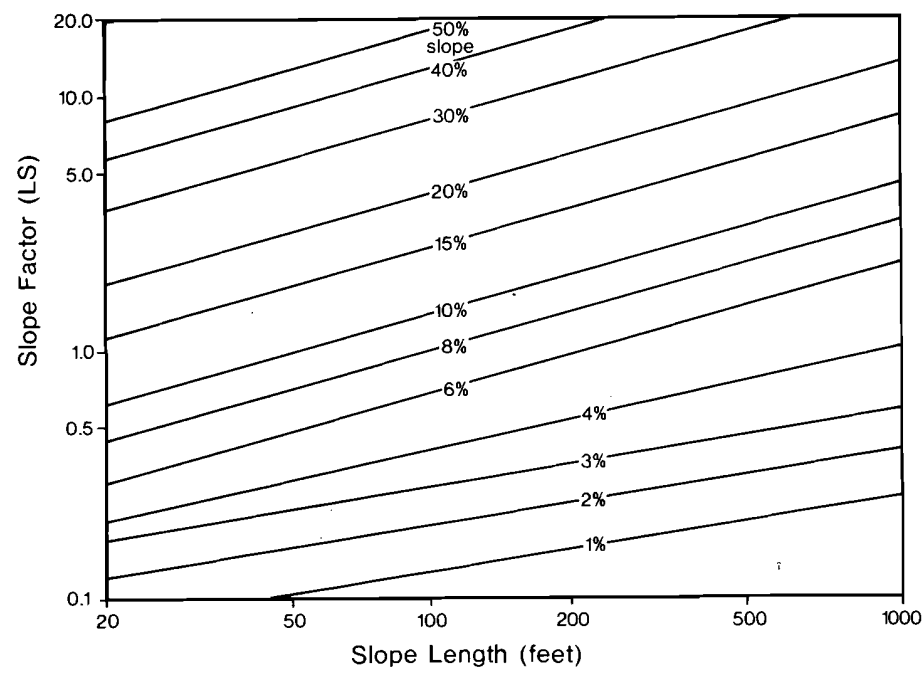

Fig. 7. Relationship of the slope erodibility factor $(L S)$ to percent slope and slope length (Wischmeier and Smith, 1978). 
The average slope of each land type in the Jalapa region (Table IV) was estimated by means of field transects across each land system, measuring slope with a clinometer every $25 \mathrm{~m}$ until 100 slopes had been measured on each topographic element. The depth of the A-horizon was measured with an auger at 10 random points on each topographic element to get an approximation of how much erosion each land type could tolerate.

\section{Food consumption and production}

Regional autonomy in food production is not a reality in Mexico and is not likely to be so in the foreseeable future. However, evaluating regional carrying capacity to plan for urban food supply zones is a useful planning exercise. The Jalapa land-use game contained separate food production goals $\left(g_{k}\right)$ for the food categories listed in Table III. The goal for a particular year was set on the basis of the projected food consumption for that year. Food production that equaled or exceeded consumption would indicate self-sufficiency.

Consumption. Estimating food consumption for the Jalapa region proceeded in two stages: (1) estimates of per-capita consumption of different kinds of food for both rural and urban populations (Table VI); (2) projections of rural and urban populations in the Jalapa region (Table VII).

Per-capita food consumption was based on a survey of household income and expenses conducted by the University of Veracruz Economics Institute (1975). The most significant finding was the increased use of animal products by urban dwellers. Because animal products require more land than plant products to produce a similar quantity of calories or protein (Table VIII), urban dwellers use twice as much land as rural inhabitants to feed themselves.

\section{TABLE VI}

Quantities of major foods consumed per person and the amount of land necessary to provide that amount of food

\begin{tabular}{|c|c|c|c|c|}
\hline \multirow[t]{2}{*}{ Food } & \multicolumn{2}{|l|}{ Urban } & \multicolumn{2}{|l|}{ Rural } \\
\hline & $\begin{array}{l}\text { Food consumed } \\
\left(\mathrm{kg} \text { year }^{-1}\right)\end{array}$ & $\begin{array}{l}\text { Land required } \\
\text { (ha) }\end{array}$ & $\begin{array}{l}\text { Food consumed } \\
\left(\mathrm{kg}^{-1} \text { year }^{-1}\right)\end{array}$ & $\begin{array}{l}\text { Land required } \\
\text { (ha) }\end{array}$ \\
\hline Maize/Beans & $64 / 39$ & 0.032 & $153 / 27$ & 0.076 \\
\hline Fice & 15 & 0.004 & 10 & 0.003 \\
\hline Wheat & 27 & 0.027 & 14 & 0.014 \\
\hline Root crops & 34 & 0.005 & 13 & 0.002 \\
\hline Fruit & 45 & 0.008 & 22 & 0.004 \\
\hline Vegetables & 89 & 0.015 & 40 & 0.007 \\
\hline Meat & 37 & 0.410 & 11 & 0.123 \\
\hline Milk & 222 & 0.121 & 63 & 0.034 \\
\hline Sugar & 34 & 0.001 & 26 & 0.001 \\
\hline Total & & 0.622 & & 0.264 \\
\hline
\end{tabular}


TABLE VII

Population of the Jalapa region

\begin{tabular}{lllr}
\hline \multirow{2}{*}{ Year } & Population & & \\
\cline { 2 - 4 } & Rural & Urban & Total \\
\hline 1978 & 313,000 & 290,000 & 603,000 \\
2000 & 444,000 & 746,000 & $1,190,000$ \\
\hline
\end{tabular}

TABLE VIII

Typical levels of the annual production of protein and calories with existing (prevailing technology, rainfed) land-use systems in the humid warm-temperate zone $\mathrm{e}^{\mathrm{a}}$

\begin{tabular}{lll}
\hline & $\begin{array}{l}\text { Calories } \\
\left(\text { Kcal } \times 10^{6} \mathrm{ha}^{-1}\right)\end{array}$ & $\begin{array}{l}\text { Protein } \\
\left(\mathrm{kg} \mathrm{ha}^{-1}\right)\end{array}$ \\
\hline Maize-beans & 6.2 & 180 \\
Vegetables & 2.7 & 170 \\
Fruit & 2.4 & 36 \\
Milk & 1.1 & 64 \\
Meat & 0.3 & 18
\end{tabular}
${ }^{a}$ Based on calorie and protein contents of each food (Hernandez et al., 1977) and typical
yields per hectare.

Population projections for the Jalapa region were based upon an exponential extrapolation of rural and urban population growth between 1960 and 1970. Because the fertility rate could drop during the coming years, the simple extrapolations we used could be considered estimates of the maximum population to be expected. Using official census figures for 1960 and 1970 , the instantaneous rate of population growth was calculated as: $r=\log _{e}(1970$ population/1960 population)/ 10 years. Table VII shows that the instantaneous rate of urban population growth was $4.3 \%$ per year as compared to only $1.6 \%$ per year for the rural population. Hence, although only half the population was urban in 1978, the urban population could be expected to increase as much as 2.6 times by the year 2000 and could constitute nearly two-thirds of the total population by that date.

Production. To predict the food production and farm income that would actually occur for a given land allocation (i.e., $y_{k}$ for food production and income goals), it was necessary to estimate crop production for each combination of land type and land-use system. In a manner comparable to the estimation of erosion, production was assumed to be the product of potential production irom a land-use system and the fraction of that production that could be realized on a particular land type. Production $=P_{i} p_{j}$, where $P_{i}$ is the 
production for land-use system $i$ expected from the most productive land type available; $p_{j}$ is the productivity of land type $j$ relative to the most productive land type in the region.

The production equation assumed that relative productivities of 2 land types were the same for all land uses. To the extent this assumption is valid, this simple equation is a useful approximation because it would not be feasible in most land planning situations to identify explicitly the production for every land-use system on every land type. The validity of the approximation, however, requires further verification.

Information about the production $\left(P_{i}\right)$ and sustainability of land-use systems was obtained in the same interviews used to gather other information on land-use systems (see the following section on Inputs to and incomes from land-use systems). Land-use-system productions are shown in Table IX.

The biological productivity $\left(p_{j}\right)$ of each land type was evaluated empirically by a field survey to estimate net biomass productivity at the end of the growing season. Creole maize was used as the production indicator because of its occurrence on all land types throughout the Jalapa region.

The field survey (Marten and Sancholuz, 1981b) included at least 10 maize fields in each land type. Thirty maize plants in each field were sampled with respect to (1) height of the plant (meters to the highest node) and (2) diameter of the stalk (major axis of the node below the ear in centimeters). These two dimensions were previously calibrated against the total dry weight of the plant. The regression equation for estimating above-ground maize biomass

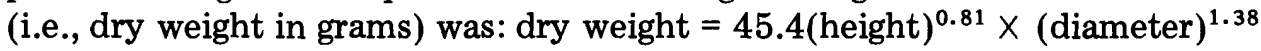
$(\mathrm{R}=0.93, n=591)$.

The number of maize plants in a $20 \times 20 \mathrm{~m}$ square was counted in each field in order to estimate the planting density of the field. The average biomass of the 30 plants was then multiplied by the number of plants per hectare to estimate above-ground maize biomass per hectare. Because this figure ignored weed production and maize root production, it fell short of the total net primary production of the field, but was considered a reliable index for comparing the productivity of different land types. The variation in productivity from one maize field to another in the same land type was such that, with a sample of 10 fields, the standard error of the estimate did not exceed $5 \%$ of the average productivity estimated for that land type.

Since the study was concerned with the inherent productivity of each land type rather than any differences that might be due to the levels of technology which were employed in the maize fields sampled, the data from all maize fields were submitted to multiple regression analysis in which maize biomass per hectare was the dependent variable and cultivation practices were independent variables. It is important to include cultivation practices, because they may be systematically different on different land types and could otherwise produce biased results. For example, poorer soils tended to be fertilized more heavily. Cultivation practices included in the regression analysis were frequency of weeding, presence of intercropping (e.g., beans), 
fertilizer application, the number of years the field had been in continuous maize production, and pesticide application. Intercropping and fertilizer application had statistically significant impacts on maize biomass (Marten and Sancholuz, 1981b).

Each land type was included as an additional independent variable; having a value of 0 or 1 depending upon whether a field was of that land type, with the result that the partial regression coefficient for each land type represented the relative maize biomass productivity on that land type, with the effects of cultivation practices removed. Although planting density is a cultivation practice that has a strong positive correlation with production per hectare, it was not included as an independent variable because it was considered to be an integral part of the production response.

The resulting estimates of productivities of the different land types applied only to the year of sampling (1977). The weather experienced by a particular land type, particularly rainfall, fluctuates from year to year and the biomass production on that land type fluctuates accordingly. As the study was interested in the long-term production of each land type, an adjustment was made based on the weather over many years compared with the weather during the 1977 growing season. The measure of weather was "realizable evapotranspiration", which was defined as the lesser of pan evaporation or precipitation.

It was observed that the maize biomass production at different sites is proportional to realizable evapotranspiration (Fig. 8). The scatter of points about the trend in Fig. 8 can be explained largely by soil depth, soil organic matter content and application of nitrogen fertilizer (Marten and Sancholuz, $1981 \mathrm{~b})$. The long-term productivity $\left(p_{j}\right)$ of each land type was estimated as $p_{j}=(1977$ productivity $) \times$ (long-term realizable evapotranspiration/1977 realizable evapotranspiration).

Productivity estimates based on evapotranspiration are approximations which require further verification, but they are potentially useful because they can be based on easily obtainable weather records, thereby minimizing dependence on costly productivity surveys based on field sampling. Although it was not done, evapotranspiration could also have been used to estimate productivity from an agricultural-risk point of view, that is, the worst production to be expected in a given period, such as 5 . or 10 years.

The resulting productivity index (Table IV) applies to rainfed annual crops. Perennial crops may be able to realize some additional production outside the maize growing season. The relative productivity of each land type for perennials was estimated by the following: perennial production $=($ annual rainfed productivity) $\times$ (realizable evapotranspiration for the entire year/ realizable evapotranspiration for the maize growing season).

Actual evapotranspiration can be equal to potential evapotranspiration if water is available in excess through irrigation. The productivity to be expected with irrigation was estimated as: irrigated productivity $=$ (rainfed productivity) $\times$ (potential evapotranspiration/rainfed realizable evapotranspiration). 


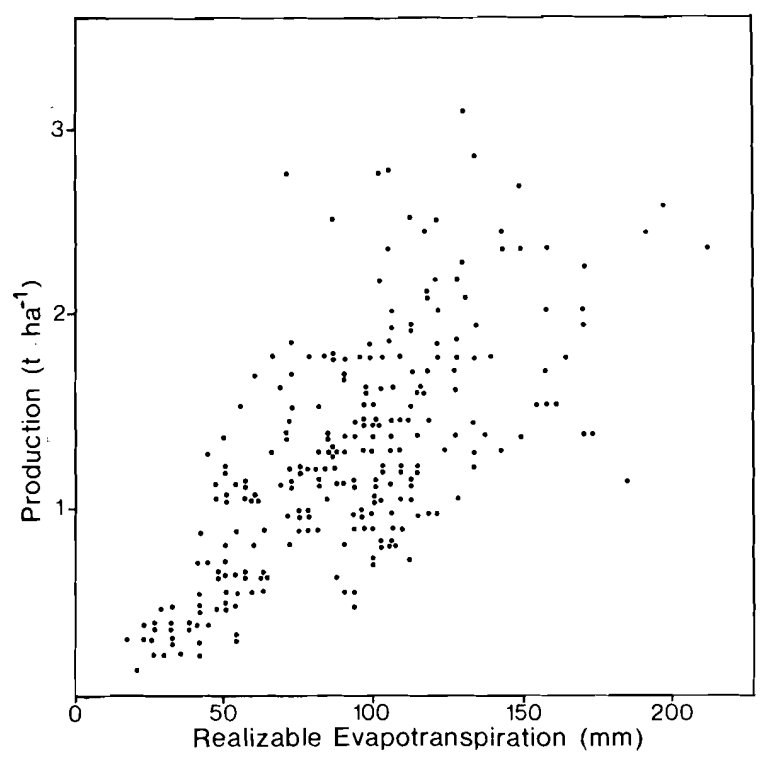

Fig. 8. Prediction of monthly above-ground dry-weight biomass production in maize fields on the basis of realizable evapotranspiration. Production $\left(\mathrm{t} \mathrm{ha}^{-1}\right)=0.0157 \times$ realizable evapotranspiration $(\mathrm{mm}), r=0.82$.

Inputs to and income from land-use systems

It was found that information on land-use systems (e.g., inputs required and income generated) was best obtained by interview. Twenty agricultural agents and agronomists who worked in the region or at experiment stations nearby were interviewed. They were asked for opinions on how well the land-use systems would perform on each of the land types. Twenty-fifty farmers were interviewed in each geomorphological system on their evaluation of the suitability of different land types for different land uses in their vicinities. Each land-use system's requirements for agricultural chemicals, labor and machinery, as well as the total costs of production and income generated, are shown in Table IX.

The land-use game was structured to operate with two definitions of regional farm income: (1) The sum of net profits for all land used in the region. This is based on gross income (i.e., value of the crop multiplied by quantity produced) minus all costs including labor. (2) The sum of net profits and labor costs for all land used in the region. This is the same as gross income minus all costs except labor and represents all earnings, whether profit or wages. The second definition of income is used in the Results presented later.

Each land-use system was also characterized by the agricultural support services required. Constraints on services in a given scenario were expressed as the maximum "equivalent" square kilometers of modern land-use systems 
that would be allowed in that scenario. "Equivalent" was necessary because the area that could be covered by government services depended in part upon farm sizes. (The same services can cover a larger area if farms are larger.) Most farmholdings in the Jalapa region are 1-10 ha in size, but beef-cattle ranches in the tropical zone are larger (hundreds of hectares). As the same amount of agricultural service can support a tropical-zone cattle ranch 5 times the size of other farms, an "equivalent" $1 \mathrm{~km}^{2}$ of agricultural services was assumed to support $5 \mathrm{~km}^{2}$ of modern tropical cattle ranch or $1 \mathrm{~km}^{2}$ of any other modern land-use system.

Constraints on irrigation were also expressed in square kilometers, on the assumption that the size of the irrigation system was the factor limiting the quantity of land-use systems that require irrigation. Water supply could become a limiting factor at high levels of irrigation, however, and if that were so, it would be desirable in future versions of the Jalapa land-use game to specify limitations on the water supply as well. Optimal water allocation would then depend upon river flows, ground water levels, rainfall patterns and the water consumption of different use systems.

\section{Sustainability of land-use systems}

A land-use system that cannot be sustained on a particular land type should be excluded from that land type in the course of sound planning. Optimal solutions in the game, therefore, were limited to those combinations of land-use systems and land types that could be sustained without ecological deterioration. A two-way table (Table $\mathrm{X}$ ) summarizes the results from interviews, numbers ("yes") and blanks ("no") indicating which of 56 land-use systems were viable on each of the 33 land types. Yes-no evaluation of sustainability did not include perceptions of productivity or erosivity because these were treated separately.

\section{Land inventory}

Once land types were identified and defined, it was possible to inventory through aerial photographs the surface area $\left(a_{j}\right)$ of each land type in the region (Table IV) and the actual land uses on each land type (Table XI). Actual land uses represented the "real world" solution and could be compared with optimal land allocation solutions given by the land-use game for various imaginary scenarios (e.g., Table XII).

After marking the boundaries of each geomorphological system on aerial photographs, the area of each was measured with a planimeter. To estimate the surface area of each land type (i.e., topographic element) within a geomorphological system, the percentage of each topographic element within that system had to be estimated and each percentage multiplied by the known area of the system.

This was done with an overlay grid of white dots at $1-\mathrm{cm}$ intervals (equivalent to 500-m intervals on the ground) on one of the pair of photographs viewed under a stereoscope. The land type immediately to the right of each 
Characteristics of crops and animal products in the Jalapa region ${ }^{\mathrm{a}}$

\begin{tabular}{|c|c|c|c|c|c|c|c|c|}
\hline \multirow[t]{2}{*}{ Land-use system } & \multirow{2}{*}{$\begin{array}{l}\text { Labor } \\
\text { (Man-days) }\end{array}$} & \multicolumn{3}{|c|}{ Costs $^{b}$ (pesos) } & \multirow{2}{*}{$\begin{array}{l}\text { Yield } \\
(\mathrm{t})\end{array}$} & \multirow{2}{*}{$\begin{array}{l}\text { Value }^{b} \\
\left({\left.\text { Pesos } t^{-1}\right)}\right)\end{array}$} & \multirow{2}{*}{$\begin{array}{l}\text { Net } \\
\text { profit }^{b}\end{array}$} & \multirow[t]{2}{*}{ Erosivity $\left(E_{i}\right.$} \\
\hline & & $\begin{array}{l}\text { Chemical } \\
\text { inputs }\end{array}$ & Mechanization & Total cost ${ }^{c}$ & & & & \\
\hline Wheat (RM) & 3 & 875 & 1245 & 2925 & 2.5 & 2000 & 2075 & 0.15 \\
\hline Barley (RP) & 14 & 0 & 0 & 1550 & 0.7 & 3500 & 900 & 0.20 \\
\hline Barley (RM) & 3 & 875 & 1245 & 2785 & 2.5 & 3500 & 5965 & 0.15 \\
\hline Maize (RP) $d$ & 32 & 400 & 0 & 3300 & 2.0 & 3100 & 2900 & 0.38 \\
\hline Maize $(R M)^{d}$ & 42 & 750 & 0 & 4400 & 4.0 & 3100 & 8000 & 0.35 \\
\hline Rice (IP) & 28 & 1480 & 1000 & 6070 & 4.0 & 3200 & 6730 & 0.35 \\
\hline Rice (IM) & 95 & 3745 & 1500 & 11400 & 7.0 & 3200 & 10500 & 0.35 \\
\hline Potatoes (RM) & 48 & 2700 & 0 & 18630 & 15.0 & 2000 & 11370 & 0.30 \\
\hline Beans (RP) & 27 & 430 & 1100 & 3775 & 1.0 & 5500 & 1745 & 0.45 \\
\hline Beans (RM) & 39 & 1145 & 1300 & 5820 & 1.8 & 5500 & 4080 & 0.45 \\
\hline$H a b a$ bean (RP) & 10 & 0 & 0 & 1570 & 0.7 & 6000 & 2630 & 0.45 \\
\hline Haba bean (RM) & 6 & 250 & 800 & 2050 & 1.8 & 6000 & 8750 & 0.45 \\
\hline Soybean (Soya) (RM) & 39 & 315 & 1300 & 4760 & 2.0 & 3900 & 3040 & 0.50 \\
\hline Peanuts (RM) & 36 & 710 & 1100 & 6010 & 4.5 & 3500 & 9740 & 0.40 \\
\hline Sesame (RM) & 31 & 660 & 1000 & 3985 & 1.2 & 6000 & 3215 & 0.40 \\
\hline Sugarcane (RP)f & 76 & 1730 & 300 & 7730 & 80.0 & 207 & 8830 & 0.18 \\
\hline Sugarcane (IM)g & 100 & 1900 & 300 & 9900 & 120.0 & 207 & 14940 & 0.18 \\
\hline Coffee (RP) & 179 & 300 & 0 & 13725 & 3.2 & 8830 & 14600 & 0.05 \\
\hline Coffee (RM) & 285 & 600 & 0 & 21975 & 8.3 & 8830 & 51000 & 0.05 \\
\hline Oranges $(R P)^{f}$ & 3 & 0 & $\mathbf{0}$ & 210 & 5.0 & 620 & 3000 & 0.02 \\
\hline Oranges $(\mathrm{RM}) \mathrm{g}$ & 54 & 4500 & 360 & 8910 & 26.0 & 620 & 7210 & 0.10 \\
\hline Apples, plums (RP) & 6 & 0 & 0 & 420 & 2.5 & 2750 & 6900 & 0.02 \\
\hline Apples, plums (RM) & 71 & 4180 & 0 & 9505 & 10.0 & 2750 & 18000 & 0.05 \\
\hline Papaya (RP) & 32 & 600 & 0 & 4000 & 15.0 & 1200 & 14000 & 0.15 \\
\hline Papaya (RM) & 42 & 1300 & 1200 & 7450 & 20.0 & 1200 & 16550 & 0.15 \\
\hline Papaya (IP) & 67 & 2800 & 1200 & 10725 & 27.0 & 1200 & 21675 & 0.15 \\
\hline Papaya (IM) & 92 & 5400 & 1200 & 15200 & 40.0 & 1200 & 32800 & 0.15 \\
\hline Mango (RP) & 23 & $\mathbf{0}$ & 0 & 3900 & 5.0 & 3070 & 11450 & 0.0 .5 \\
\hline
\end{tabular}




\begin{tabular}{|c|c|c|c|c|c|c|c|c|}
\hline Mango (RM) & 90 & 6900 & 0 & 19600 & 13.0 & 3070 & 22200 & 0.10 \\
\hline Mango (IM) & 114 & 6900 & 0 & 22450 & 16.0 & 3070 & 26670 & 0.10 \\
\hline Ciruelo/nanche $(\mathrm{RM})^{\mathrm{h}}$ & 22 & 650 & 900 & 3650 & 4.5 & 2800 & 8950 & 0.10 \\
\hline Zapote/tamarindo (RM) & 54 & 3890 & 1600 & 9540 & 10.0 & 2700 & 17460 & 0.10 \\
\hline Pineapple (IM) & 168 & 3300 & 800 & 20900 & 60.0 & 930 & 34900 & 0.15 \\
\hline Bananas (RM)f & 20 & 0 & 0 & 1400 & 12.0 & 800 & 7600 & 0.05 \\
\hline Bananas (IM)g & 103 & 2600 & 800 & 12100 & 40.0 & 800 & 19900 & 0.05 \\
\hline Cassava (RP) & 40 & 600 & 0 & 4400 & 6.0 & 1370 & 3820 & 0.40 \\
\hline Cassava (RM) & 75 & 2400 & 1200 & 9425 & 29.0 & 1370 & 17975 & 0.40 \\
\hline Cucumber, watermelon (IP) & 56 & 3600 & 1800 & 9700 & $\begin{array}{l}12 / \\
19^{j}\end{array}$ & $\begin{array}{l}2000 / \\
1500^{j}\end{array}$ & 16000 & 0.55 \\
\hline Cucumber, watermelon (IM) & 80 & 9000 & 3300 & 18000 & $\begin{array}{l}24 / \\
35^{j}\end{array}$ & $\begin{array}{l}2000 \\
1500^{j}\end{array}$ & 32000 & 0.55 \\
\hline Tomato (RP) & 66 & 3100 & 1000 & 9200 & 6.5 & 3000 & 10300 & 0.55 \\
\hline Tomato (IP) & 191 & 3100 & 1000 & 18100 & 25.0 & 3000 & 56900 & 0.55 \\
\hline Tomato (IM) & 400 & 7800 & 1400 & 29080 & 30.0 & 3000 & 60900 & 0.55 \\
\hline Sweet potato (RP) & 53 & 1200 & 0 & 6175 & 8.0 & 2700 & 15425 & 0.40 \\
\hline Sweet potato (RM) & 76 & 2400 & 1500 & 9800 & 12.0 & 2700 & 22600 & 0.40 \\
\hline Sweet potato (IM) & 86 & 2400 & 1500 & 10750 & 25.0 & 2700 & 56750 & 0.40 \\
\hline Chili peper (RP) & 53 & 1200 & 0 & 7200 & 5.5 & 3500 & 12000 & 0.55 \\
\hline Chili peper (RM) & 76 & 2400 & 1900 & 10200 & 10.0 & 3500 & 24800 & 0.55 \\
\hline Pinonchillo $(\mathrm{RM})^{\mathbf{k}}$ & 50 & 0 & 0 & 3750 & 17.5 & 460 & 4300 & 0.05 \\
\hline Colza (RM) ${ }^{1}$ & 36 & 750 & 1200 & 4700 & 1.8 & 6500 & 7000 & 0.40 \\
\hline Ramon $(\mathrm{RM})^{\mathrm{m}}$ & 3 & 0 & 0 & 225 & 50.0 & 250 & 12200 & 0.01 \\
\hline Milk (RP)n & 10 & 0 & 0 & 750 & $1.83^{\circ}$ & 4800 & 8000 & 0.02 \\
\hline Milk (RM)n & 40 & 2000 & 0 & 8000 & $11.000^{\circ}$ & 4800 & 44800 & 0.01 \\
\hline Beef (RP) & 10 & 0 & 0 & 675 & 0.054 & 15000 & 2195 & 0.02 \\
\hline Beef (RM)g & 30 & 1000 & 0 & 3025 & 0.162 & 15000 & 5597 & 0.01 \\
\hline Beef $(I M)^{g}$ & 66 & 1000 & 0 & 5700 & 0.648 & 15000 & 22680 & 0.01 \\
\hline
\end{tabular}

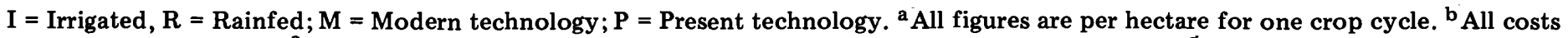
and prices are for 1977 . $^{\mathrm{c}}$ Total cost is calculated assuming that one man-day costs 70 Mexican pesos. ${ }^{d}$ The production indicated here is for good soil in the temperate, subtropical, or tropical zone. Yields in the arid altoplano zone (Perote) are half those indicated.

${ }^{\mathrm{e}}$ Vicia faba (similar to lima bean). ${ }^{\mathrm{f}}$ Subtropical zone. ${ }^{\mathrm{g}}$ Tropical coastal zone. ${ }^{\mathrm{h}}$ Spondias mombin and Spondias purpurea/Byrsonima crassifolia (tropical fruits). ${ }^{\mathrm{i}}$ Mankilara zapota/Tamarindus indica (tropical fruits). ${ }^{\mathrm{j}}$ The first figure is for cucumber and the second for watermelon. ${ }^{\mathrm{k}}$ Jatropha curcas (nut). ${ }^{1}$ Brassica campestris (vegetable oil). ${ }^{\mathrm{m}}$ Brossimum alecastrum (cattle tree forage). ${ }^{\mathrm{n}}$ Temperate-zone milk production. ${ }^{\circ}$ Thousands of liters. 

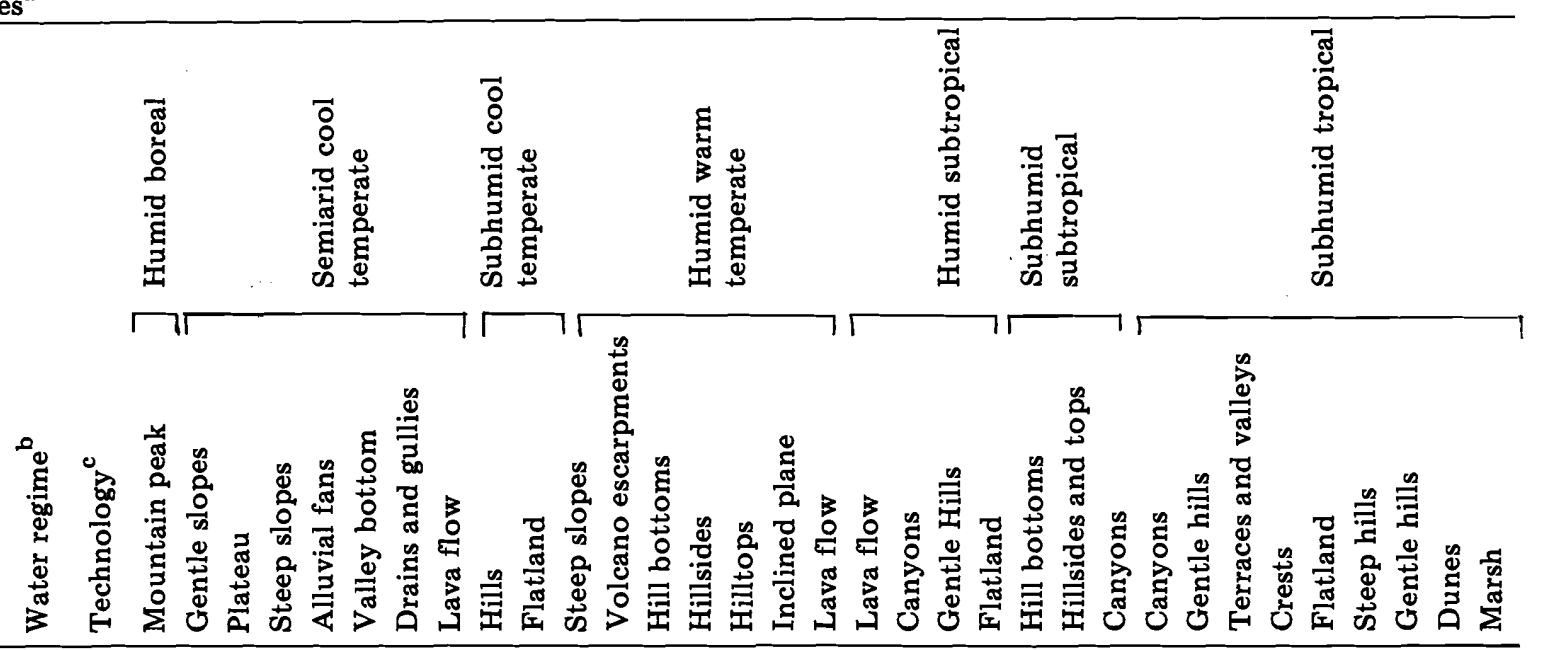

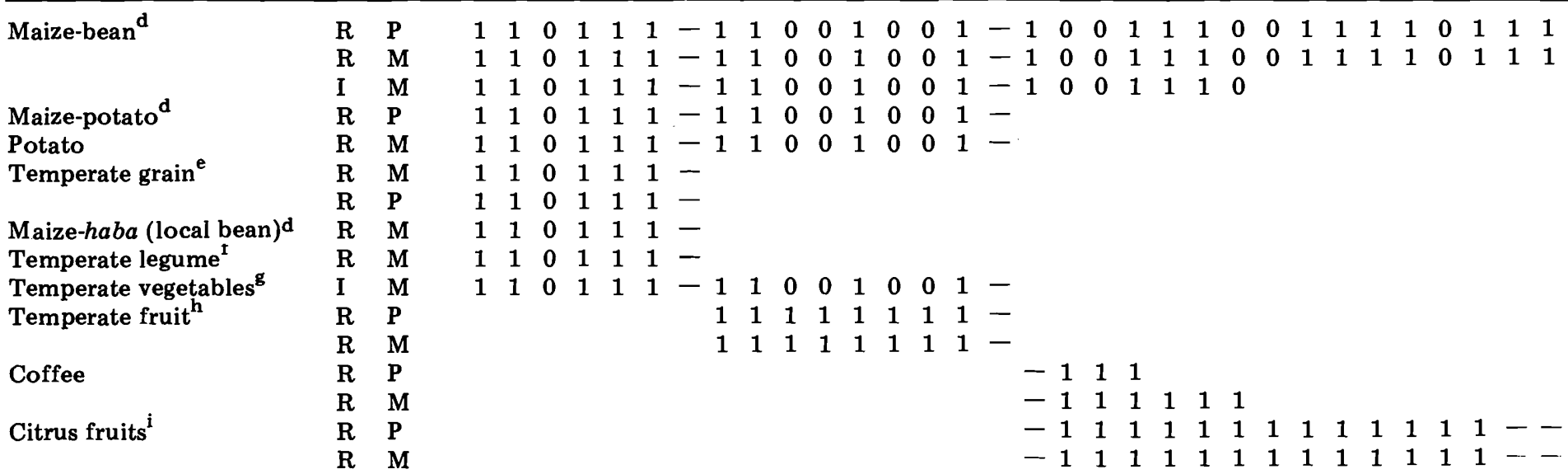




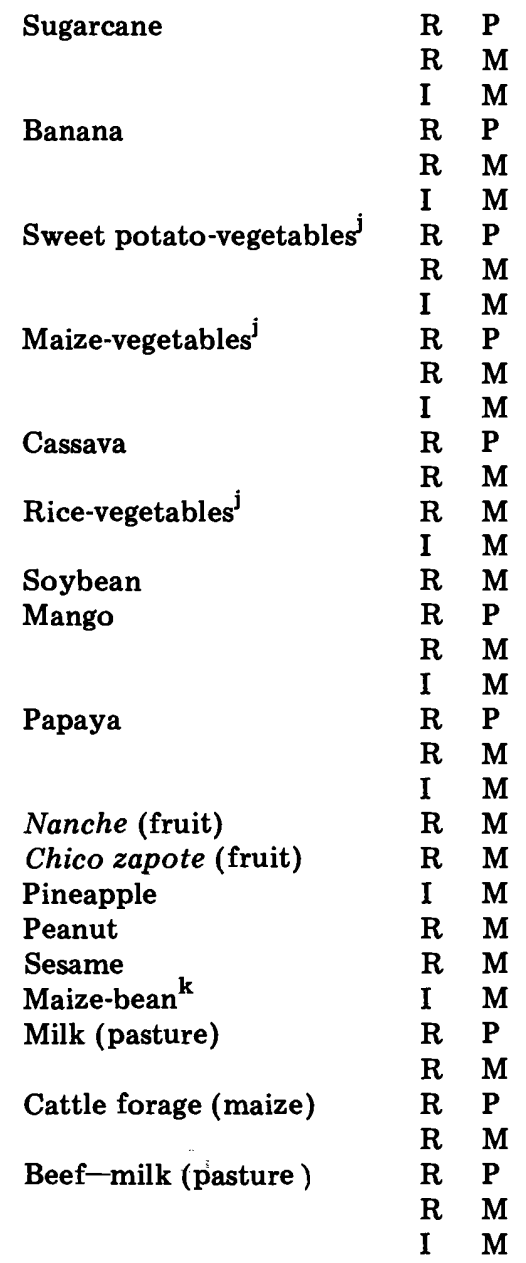

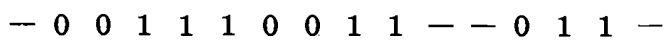

$\begin{array}{llllllllllllllll}- & 0 & 0 & 1 & 1 & 1 & 0 & 0 & 1 & 1 & - & -0 & 1 & 1 & -\end{array}$ $\begin{array}{llllllllllllllll}- & 0 & 0 & 1 & 1 & 1 & 0 & 0 & 1 & 1 & - & - & 0 & 1 & 1 & -\end{array}$ $\begin{array}{llllll}-1 & 1 & 1 & 1 & 1 & 1\end{array}$

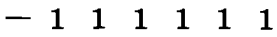

$\begin{array}{llllllllllllllll}- & 1 & 1 & 1 & 1 & 1 & 1 & 1 & 1 & 1 & - & - & 0 & 0 & - & \cdots\end{array}$ $1 \quad 1--000-\cdots$

$\begin{array}{llllllll}0 & 1 & 1 & - & 0 & 0 & -\end{array}$

$\begin{array}{llllllll}0 & 1 & 1 & - & 0 & 0 & -\end{array}$

$\begin{array}{llllllll}0 & 1 & 1 & - & 0 & 1 & -\end{array}$

$\begin{array}{lllllllll}0 & 1 & 1 & - & 0 & 1 & -\end{array}$

$\begin{array}{lllllllll}0 & 1 & 1 & - & 0 & 1 & - & -\end{array}$

$\begin{array}{lllllllll}0 & 1 & 1 & 1 & 1 & 0 & 0 & - & -\end{array}$

$\begin{array}{llllllllll}0 & 1 & 1 & 1 & 1 & 0 & 0 & - & -\end{array}$

$-11-----$

$-11-----$

$\begin{array}{lllllllll}0 & 1 & 1 & 1 & 1 & 0 & 1 & 1 & -\end{array}$ $--1--\cdots-$ $--1----\cdots$ $--1-\cdots-\cdots$ $\begin{array}{llllllllll}1 & 1 & 1 & 1 & 1 & 1 & 1 & - & -\end{array}$ $\begin{array}{llllllllll}1 & 1 & 1 & 1 & 1 & 1 & 1 & - & -\end{array}$

$\begin{array}{lllllllll}1 & 1 & 1 & 1 & 1 & 1 & 1 & - & -\end{array}$

$\begin{array}{lllllllll} & 1 & 1 & 1 & - & - & 1 & 1 & -\end{array}$

$\begin{array}{lllllllll}1 & 1 & 1 & 1 & 1 & 1 & 1 & - & -\end{array}$

$\begin{array}{llllllll}0 & 1 & 1 & - & 0 & 1 & -\end{array}$ $\begin{array}{llll}0 & 1 & 1 & -\end{array}$ $\begin{array}{lllllllll}0 & 1 & 1 & - & - & 0 & 1 & 1 & -\end{array}$ $\begin{array}{lllllllll}0 & 1 & 1 & 1 & 1 & 0 & 1 & 1 & 1\end{array}$

$\begin{array}{llllllll}1 & 1 & - & - & 1 & 1 & 1 & 1\end{array}$

$\begin{array}{lllllllll}1 & 1 & - & - & 1 & 1 & 1 & 1 & -\end{array}$

$\begin{array}{lllllllllllll}1 & 1 & 0 & 0 & 1 & 0 & 0 & 1 & - & 0 & 0 & 1\end{array}$

$\begin{array}{lllllllllllll}1 & 1 & 0 & 0 & 1 & 0 & 0 & 1 & - & 0 & 0 & 1\end{array}$

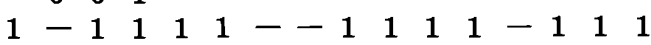

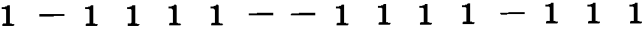

$\begin{array}{llllllllllllllll}1 & - & 1 & 1 & 1 & 1 & - & - & 1 & 1 & 1 & 1 & - & 1 & 1 & 1\end{array}$ 


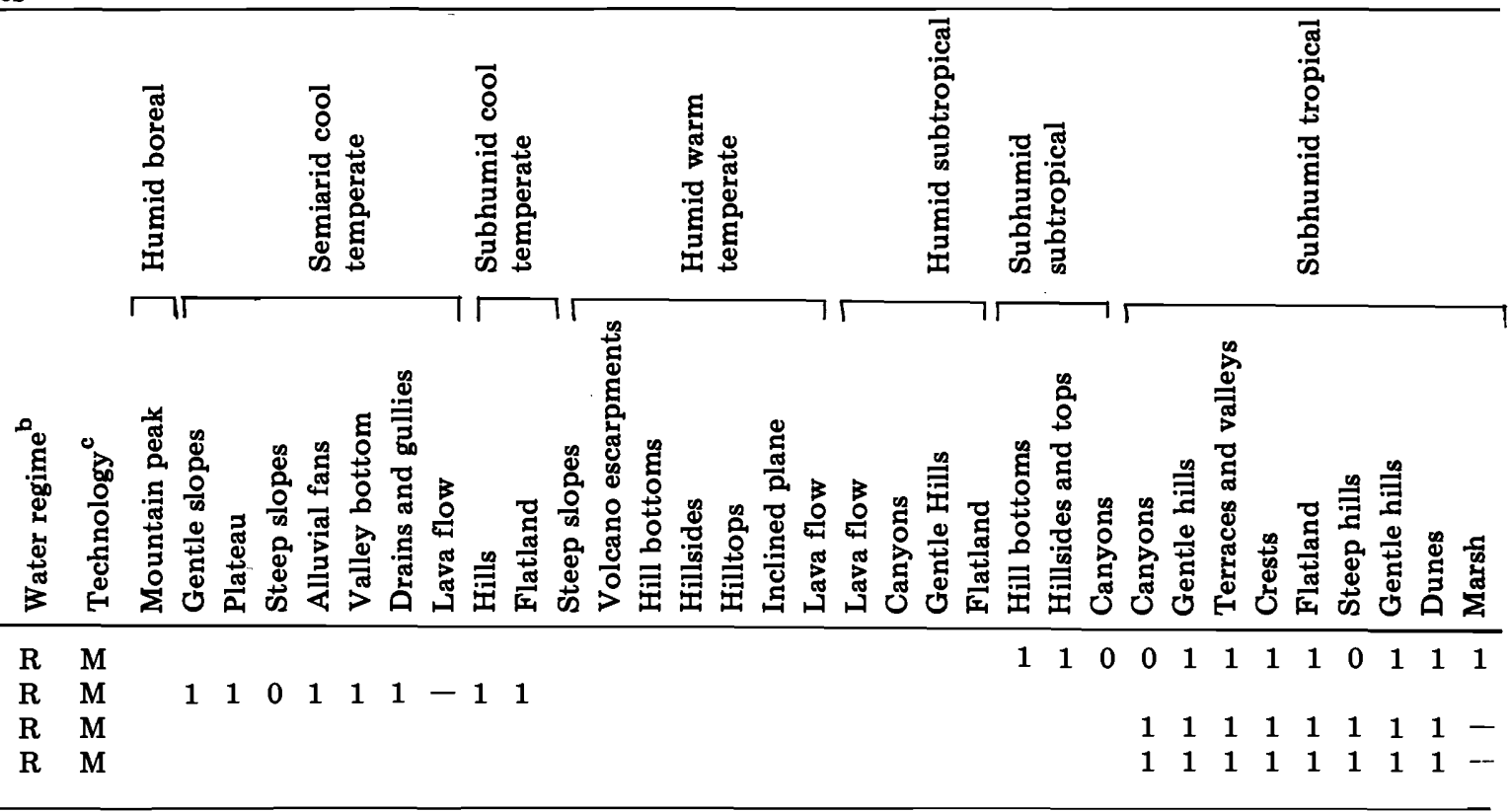

${ }^{a}$ Blank = not feasible for climatic reasons; $-=$ suitable climate but excluded because of edaphic limitation; $0=$ possible (i.e., suitable soil and climate, but erosion excessive $\left(>60 \mathrm{t} \mathrm{ha}^{-1}\right.$ year $\left.\left.{ }^{-1}\right)\right) ; 1=$ sustainable. ${ }^{b} \mathrm{R}=$ rainfed; $\mathrm{I}=$ irrigated. ${ }^{\mathrm{c}} \mathrm{P}=$ present technology; $\mathrm{M}=$ modern technology. ${ }^{d}$ Interplanted. ${ }^{e}$ Wheat or barley. ${ }^{f}$ Haba or peas. ${ }^{\mathrm{g}}$ Lettuce, cabbage, spinach, or chard. ${ }^{\mathrm{h}}$ Peach, plum, apple, or pear. ${ }^{i}$ Orange or lemon. ${ }^{j}$ Rotation of first crop in summer with vegetables (tomato, cucumber, or watermelon) in winter. ${ }^{k}$ Two maize crops per year, plus beans in winter. 


\section{TABLE XI}

Present land use in the Jalapa region ${ }^{a, b}$

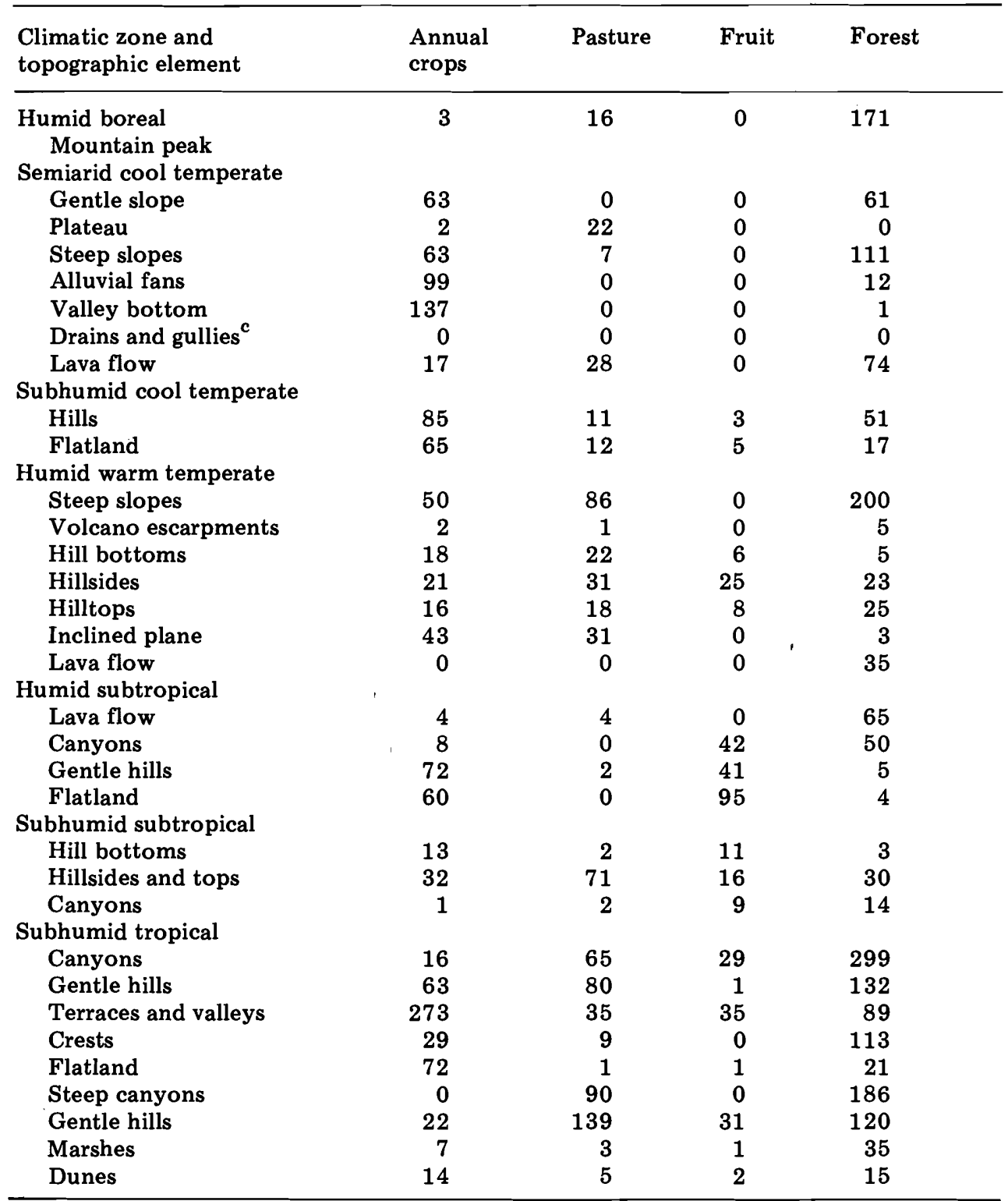

${ }^{a}$ Area in square kilometers. ${ }^{b}$ For each land type, the sum of the surface areas in the uses specified in this Table may be less than the total amount available as listed in Table IV because of uses such as bare ground and urban use, which are not included here. ${ }^{c}$ Denuded land. 
dot was noted as well as the land use at the same point: mature forest, secondary forest, coffee plantation, fruit orchard, pasture, maize field, sugarcane or other agricultural use. The use was identified on the photograph by tone, texture and form based on field observations of different land uses and how they appeared on the photographs. For example, maize and pasture have a similar tone on a photograph but a maize field lacks trees and has regular borders, whereas a pasture has scattered trees and an irregular boundary. The result of the counts in a particular geomorphological system was a two-way table showing the extent of each land type and the extent of its observed uses (Table XI).

\section{RESULTS AND CONCLUSIONS}

The Jalapa land-use game permits exploration of land-use planning objectives and priorities and the consequences of varying government infrastructure support for agricultural production. The game was used to explore the trade-offs between environmental objectives and other planning objectives by asking the following questions: (1) What are the environmental costs of increasing food production or farm incomes? (2) How can increased government support services for agriculture affect the trade-offs among land-use objectives? (3) What land-use systems should be encouraged as more agricultural services become available?

It can be illustrated how these questions may be answered by using two priority rankings of the planning objectives listed in Table III. The rankings represent two extreme cases in the relative emphasis placed on minimizing erosion vs. maximizing farm incomes.

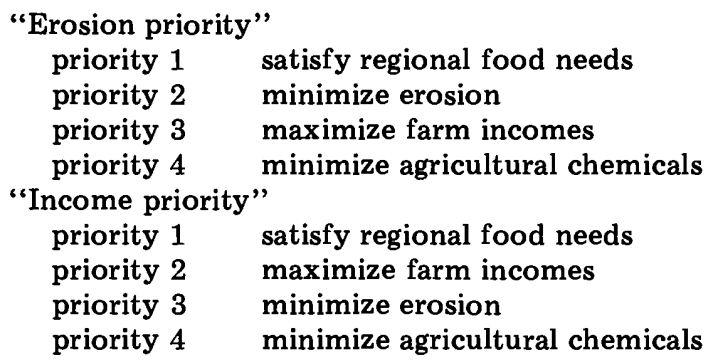

Regional food consumption levels, estimated for 1978 and projected up to the year 2000, were used as reference points for necessary food production (Table III). A food production objective was considered satisfied if production equalled or exceeded the specified goal. If a surplus occurred, the excess was considered available for export from the region as a cash crop.

In addition to the objective to minimize erosion, a maximum annual erosion of no more than $60 \mathrm{t} \mathrm{ha}^{-1}$ was made a constraint for each land use. Because any use other than forest would result in more erosion than this amount on some land types in the region, only 4190 of the $4750 \mathrm{~km}^{2}$ were eligible for uses other than forests. 
Production goals for forest products were not included in these examples because figures were not yet available for the consumption of forest products in the region. Because forest uses (e.g., reserves, lightly managed forest, plantations, etc.), were not included as separate land-use systems, forest uses were not explored in the depth they deserved. For comprehensive coverage, however, multi-objective planning should consider forest products and services, including construction materials, fibers, recreation, watershed and conservation of endangered species and ecosystems.

Each computer optimization run is a scenario, a unique set of objectives, priorities and agricultural support services. For each of the scenarios hypothetical limits were scanned for agricultural support services and irrigation facilities, ranging from none to an unlimited quantity. The possibilities for exploring different scenarios with the game are immense, and only a small sampling can be presented here. Tables XII and XIII show the results of 4 scenarios, all directed at satisfying 1978 food requirements in the region.

\section{Results from income priority scenarios}

When increasing farm incomes had a higher priority than minimizing erosion (Tables XII and XIII, columns 2 and 3), the entire $4190 \mathrm{~km}^{2}$ suitable for use more intensive than forest were assigned agricultural uses in the optimal solution. When agricultural assistance and irrigation were restricted to their 1978 levels $\left(100 \mathrm{~km}^{2}\right.$ each), maize, bean and potato production were concentrated on the more level soils of the temperate zone as well as the subtropical zone's poorer (but flat) soils (Table XII, column 2). Production of these crops was only sufficient to satisfy regional needs, except for a potato surplus 30-times greater than regional needs. Modern inputs were concentrated on vegetable and cattle production in the tropical zone; this satisfied regional needs. Most of the steeper land in the temperate zone was used for dairy cattle in this scenario, generating a regional surplus of milk. The steepest usable land in the temperate zone, as well as all usable land in other climatic zones that was not required for regional food needs, was devoted to fruit trees (including coffee) and yielded a fruit surplus 110-times greater than the regional requirement. Thus, the large quantity of sloping land in the Jalapa region was best used to grow fruit, which generated a commercial surplus that added to income.

Note that an objective for risk minimization was not included in the game runs. Actual land use in the Jalapa region includes far fewer fruit trees (except coffee) than the optimal solution of this scenario would suggest, probably because of risks from pests and disease, though capital and marketing limitations may also be responsible.

When maximizing income remained the priority over minimizing erosion, but no limit was placed on agricultural services and irrigation (Table XII, column 3), most maize production was shifted to the tropical zone and generated a yield 3-times greater than the regional need. Otherwise, the same patterns and surpluses of the 1978 input scenario pertained, with the addi- 
TABLE XII

Examples of optimal land allocations for meeting 1978 regional food needs ${ }^{a}$

Climatic zone and

topographic element
Higher priority to

maximize income

\begin{tabular}{ll}
\hline 1978-level & Unlimited \\
technology & techonlogye
\end{tabular}

Semiarid cool temperate

Gentle slope

Plateau

Steep slopes

Alluvial fans

Valley bottom

Drains and gullies

Lava flow

Subhumid cool temperate

Hillside

Flatland

Humid warm temperate

Steep slopes

Volcano escarpments

Hill bottoms

Hillsides

Hilltops

Inclined plane

Lava flow

Humid subtropical

Lava flow

Canyons

Hills

Flatland

Subhumid subtropical

Hill bottoms

Hillsides and tops

Canyons $\begin{array}{ll}\text { Maize-potato } & \text { Temperate } \\ \text { vegetables } \\ \text { Maize-potato } & \text { Temperate } \\ & \text { vegetables }\end{array}$

Milk $^{\mathrm{b}}$

Maize-potato Temperate vegetables

Maize-potato Temperate vegetables

Maize-potato Temperate vegetables

Maize-bean Temperate vegetables

Maize-potato Temperate Maize-bean vegetables

Temperate Temperate fruit Temperate fruit Maize-potato Maize-potato Milk

Milk Milk

Milk Milk

Maize-potato Milk

Maize-bean

Coffee

Coffee

Coffee

Banana

Coffee

Maize-bean

Banana

Banana

Maize-bean

Coffee

Coffee

Coffee

Coffee

Coffee

Coffee
Higher priority to minimize erosion

1978-level Unlimited technology techonlogye

\section{Wheat} Maize-potato Maize-potato Temperate vegetables

- $\quad$ -

Wheat

Maize-bean
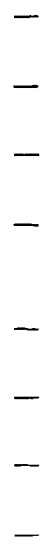

$-$

$-$

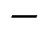

Maize-bean

Banana

Cattle

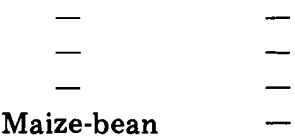


TABLE XII (continued)

\begin{tabular}{|c|c|c|c|c|}
\hline \multirow[t]{2}{*}{$\begin{array}{l}\text { Climatic zone and } \\
\text { topographic element }\end{array}$} & \multicolumn{2}{|c|}{$\begin{array}{l}\text { Higher priority to } \\
\text { maximize income }\end{array}$} & \multicolumn{2}{|c|}{$\begin{array}{l}\text { Higher priority to } \\
\text { minimize erosion }\end{array}$} \\
\hline & $\begin{array}{l}\text { 1978-level } \\
\text { technology }\end{array}$ & $\begin{array}{l}\text { Unlimited } \\
\text { technology }\end{array}$ & $\begin{array}{l}\text { 1978-level } \\
\text { technology }\end{array}$ & $\begin{array}{l}\text { Unlimited } \\
\text { technology }\end{array}$ \\
\hline \multicolumn{5}{|l|}{ Subhumid tropical } \\
\hline Canyons & $\begin{array}{l}\text { Papaya } \\
\text { (citrus fruit) }^{c}\end{array}$ & $\begin{array}{l}\text { Papaya } \\
\text { (banana) } \\
\text { Tree cattle } \\
\text { forage }\end{array}$ & - & - \\
\hline Gentle hills & $\begin{array}{l}\text { Papaya } \\
\text { (cassava) }^{c} \\
\text { Cattle (IM) } \\
\text { Tree cattle } \\
\text { forage }(R M)^{d}\end{array}$ & $\begin{array}{l}\text { Tropical } \\
\text { vegetables }\end{array}$ & $\begin{array}{l}\text { Cattle } \\
\text { Cattle (IM) } \\
\text { Tree cattle } \\
\text { forage (RM) }\end{array}$ & - \\
\hline Terrace and valley & $\begin{array}{l}\text { Papaya } \\
\text { (mango) }^{c} \\
\text { Tropical } \\
\text { vegetables }\end{array}$ & $\begin{array}{l}\text { Tropical } \\
\text { vegetables }\end{array}$ & $\begin{array}{l}\text { Cattle } \\
\text { Maize (IM) } \\
\text { Rice-vegeta- } \\
\text { bles (IM) }\end{array}$ & $\begin{array}{l}\text { Tree cattle } \\
\text { forage } \\
\text { Banana }\end{array}$ \\
\hline Crests & $\begin{array}{l}\text { Papaya } \\
\text { (cattle) }^{c}\end{array}$ & $\begin{array}{l}\text { Cattle } \\
\text { Maize }\end{array}$ & Cattle & - \\
\hline Flatland & $\begin{array}{l}\text { Papaya } \\
\text { (cattle) }^{c}\end{array}$ & $\begin{array}{l}\text { Papaya } \\
\text { (Maize) }^{c}\end{array}$ & Cattle & $\begin{array}{l}\text { Tree cattle } \\
\text { forage }\end{array}$ \\
\hline Steep canyons & $\begin{array}{l}\text { Papaya } \\
\text { (citrus fruit) }^{c}\end{array}$ & $\begin{array}{l}\text { Papaya } \\
\text { (banana) }\end{array}$ & - & - \\
\hline Gentle Hills & $\begin{array}{l}\text { Papaya } \\
\text { (citrus fruit) }^{c}\end{array}$ & $\begin{array}{l}\text { Maize- } \\
\text { vegetable } \\
\text { (pineapple) }\end{array}$ & - & - \\
\hline Marsh & Cattle & Maize & - & - \\
\hline Dune & Cattle & Cattle & Cattle & - \\
\hline
\end{tabular}

${ }^{a}$ The mountaintop land type was not included in this scenario. It is suitable only for natural reserve or forest use. ${ }^{b}$ In this scenario, milk production was permitted on the steep slopes of the mountain zone. However, the suitability of cattle for this land type is questionable. ${ }^{c}$ The crop in parentheses is indicated as the substitute for papaya if papaya is not feasible due to papaya virus. $d$ All land use systems in this column are 'prevailing technology, rain-fed' unless specified as modern technology: $I M=$ modern use system with irriga-

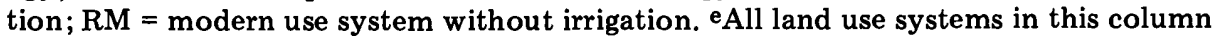
employ modern technology, as well as irrigation where appropriate.

tion of a surplus vegetable supply 190-times greater than regional needs, from irrigated vegetables grown on the alluvial soils of the semiarid cool-temperate zone (Perote) and tropical zone (Actopan). Thus, with unlimited production inputs, it presumably would be possible to generate enormous commercial surpluses of both fruits and vegetables. However, this level of fruit and vegetable production could be realized only with the support of extensive government services.

At both levels of agricultural services for the "Income Priority" scenarios (Table XIII, columns 2 and 3 ) the erosion was very high, though not significantly higher than what was actually occurring in the Jalapa region in 1978. Regional agricultural chemical applications were extremely high in the op- 


\section{TABLE XIII}

Results of optimal land allocations meeting Jalapa region food requirements for 1978 compared with present use

\begin{tabular}{|c|c|c|c|c|c|}
\hline & \multicolumn{2}{|c|}{$\begin{array}{l}\text { Higher priority } \\
\text { to maximize income }\end{array}$} & \multicolumn{2}{|c|}{$\begin{array}{l}\text { Higher priority } \\
\text { to minimize erosion }\end{array}$} & \multirow[t]{2}{*}{$\begin{array}{l}\text { Present } \\
\text { use }(1978)^{a}\end{array}$} \\
\hline & $\begin{array}{l}\text { 1978-Level } \\
\text { technology }\end{array}$ & $\begin{array}{l}\text { Unlimited } \\
\text { technology }\end{array}$ & $\begin{array}{l}\text { 1978-Level } \\
\text { technology }\end{array}$ & $\begin{array}{l}\text { Unlimited } \\
\text { technology }\end{array}$ & \\
\hline \multirow{2}{*}{\multicolumn{6}{|c|}{$\begin{array}{l}\text { Farm income }\left(\text { pesos } \mathrm{ha}^{-1}\right)^{\mathrm{b}, \mathrm{c}} \\
\text { Total region farm income }\end{array}$}} \\
\hline & & & & & \\
\hline$\left(\text { pesos } \times 10^{6}\right)^{c}$ & 5350 & 19350 & 830 & 746 & 1140 \\
\hline Erosion $\left(\mathrm{t} \mathrm{ha}^{-1}\right)^{\mathrm{b}}$ & 30 & 36 & 0.93 & 0.56 & 38 \\
\hline \multicolumn{6}{|l|}{ Total region erosion } \\
\hline$\left(t \times 10^{6}\right)$ & 12.6 & 15.1 & 0.14 & 0.025 & 10.4 \\
\hline Chemicals (pesos $\left.\mathrm{ha}^{-1}\right)^{\mathrm{b}}$ & 550 & 4500 & 300 & 1200 & 440 \\
\hline \multicolumn{6}{|l|}{ Total regional chemicals } \\
\hline$\left(\right.$ pesos $\left.\times 10^{6}\right)$ & 230 & 1890 & 44 & 53 & 104 \\
\hline Labor employed (pesos ha $\left.{ }^{-1}\right)^{b}$ & 35 & 123 & 21 & 41 & 33 \\
\hline \multicolumn{6}{|l|}{ Total regional labor } \\
\hline$\left(\right.$ pesos $\left.\times 10^{6}\right)$ & 15 & 52 & 3 & 1.8 & 7.9 \\
\hline Area in grain/legumes ${ }^{d}$ & 922 & 486 & 540 & 196 & 1532 \\
\hline Area in vegetables ${ }^{\mathrm{d}}$ & 6 & 1411 & 11 & 20 & \\
\hline Area in fruit ${ }^{d}$ & 2650 & 1635 & 13 & 4 & 312 \\
\hline Area in cattle $e^{d}$ & 612 & 658 & 930 & 224 & 919 \\
\hline Total area in use $e^{d, e}$ & 4190 & 4190 & 1494 & 444 & 2763 \\
\hline
\end{tabular}

${ }^{a}$ Based on the land allocations in Table XI. ${ }^{b}$ Hectares in use. ${ }^{c}$ Following the second definition of farm income presented in the section on income from land-use systems. ${ }^{d}$ Area in square kilometers. ${ }^{\mathrm{e}}$ Not counting forest use. 
timal solution for increasing income when unlimited assistance and inputs were made available, 18-times greater than actual applications in 1978.

\section{Results from erosion priority scenarios}

When a higher priority was assigned to minimizing erosion than to maximizing farm incomes (Tables XII and XIII, columns 4 and 5), the optimal solution placed only enough land in nonforest use to satisfy regional food needs with no commercial surpluses. When erosion control had higher priority with 1978 level technology (Table XII, column 4), the optimal solution concentrated agricultural services and irrigation on the tropical alluvial soils, where inputs are in fact concentrated in actual practice, for intensive rice, maize, vegetable and cattle production. Maize, wheat and potato production were allocated to the flattest land in the semiarid cool-temperate zone (Perote) and to the rich, flat soils of the subtropical zone (Coatepec), which actually grow coffee and sugarcane. Coffee is a profitable crop and occupies much of the best agricultural land in the region, but it does not contribute to food production. If food is a priority, coffee should be restricted to slopes, where it provides ecologically sound soil protection.

Requirements for additional meat and milk in the optimal allocation were met by using the tropical zone, and regional fruit needs were met with the allocation of a small amount of subtropical land. All sloping land, most of the land in the naturally productive humid warm-temperate zone, was allocated to forest only.

When minimizing erosion remained the higher priority but unlimited technology was available (Table XII, column 5), maize, bean, potato and vegetable production were concentrated in the Valley of Perote, and milk, meat and fruit production were allocated to the flat land in the tropical zone. All other land was put into forest use only. Employment was generally higher with the use of more modern technology because modern technology is generally more labor intensive than the land-use systems actually in effect in the Jalapa region at the time of the study.

Because as little land as possible was in agricultural use in the "Erosion Priority" scenarios, erosion dropped to very low levels, and chemical applications became extremely low; half the quantity actually in use in 1978 (Table XIII). Although chemical applications per hectare were high with unlimited technology (Table XIII, column 5), total chemical applications for the region were about the same regardless of the level of technology (columns 4 and 5), because less land is needed to satisfy food requirements when unlimited technology is made available.

Farm incomes per hectare when minimizing erosion were half those in the "Income Priority" scenarios, though still higher than actual incomes in 1978. Farm incomes with unlimited technology were 3-times as high as actual incomes. Total regional income and employment were considerably less than in maximum income scenarios because less land was in cultivation when erosion was minimized. 


\section{Carrying capacity}

How many people could the Jalapa region support, according to the landuse game? The answer to this question is not a single number. The number of people that could be supported is dependent upon the level of technology for agricultural production; the life-style of the region's inhabitants (particularly their patterns of consumption); and environmental standards.

With no limit on the supply of irrigation and agricultural services in support of agriculture, the Jalapa region could feed 8-times the 600,000 people in the region in 1978 if all land were allocated to agricultural use. However, this production could not be sustained without special erosion control measures on land with steep slopes. When only the land suitable for sustained agriculture without special erosion measures is allowed to receive agricultural use, and there is still no limit on the availability of agricultural services, the region could produce (theoretically) sufficient food for 5.5-times the 1978 population.

When the agricultural services available in 1978 are considered, the carrying capacity of the region would be 900,000 people (1.5-times the 1978 population) if excessively erosive land were kept out of agricultural use. Food production could be increased temporarily by $40 \%$ if erosive lands were used. The long-term carrying capacity of the region (without the use of highly erosive lands) could be $1,300,000$ people if the present level of agricultural services were doubled, and 1,540,000 people if multiplied 4 times.

These carrying-capacity projections assume that the consumption habits of the population remain the same. However, the population of the Jalapa region is urbanizing rapidly and changing its habits accordingly. If the entire population had the same dietary habits as the present urban population in the city of Jalapa (Table VI), the carrying capacity in each scenario would be reduced by $30 \%$.

\section{Prospects for food production}

The food requirements of the Jalapa region during the period of population growth and urbanization expected in the next 20 years can be considered, with the help of the land-use game, in terms of: (1) how much food the city of Jalapa and the Jalapa region will be consuming in the year 2000; (2) how much food the Jalapa region could produce with the present level of technology; (3) how much improvement in technology would be necessary to meet food needs fully and to which land uses that technology should be directed.

The population of the Jalapa region, if it grows as predicted, will double by the end of the century. Most of the growth will be in the high-consumption urban sector, which will triple in size. If the existing population and existing demand were small in comparison to the productive capacity of the land, then the rapid increase in demand would present no problem. However, 
the Jalapa region already has virtually all of its agriculturally suitable land in agricultural use; $90 \%$ of that land is being used for food production.

With "Erosion Priority" scenarios, the land-use game indicated it would be possible (with land allocated optimally) to produce sufficient food for the region at acceptable levels of erosion only if the agricultural services in support of modern technology are 4-times the present level (Fig. 9). The bulk of agricultural development would have to be directed at intensified beef production in the tropical zone and the remainder at intensified grain production (maize and rice) in the same zone.

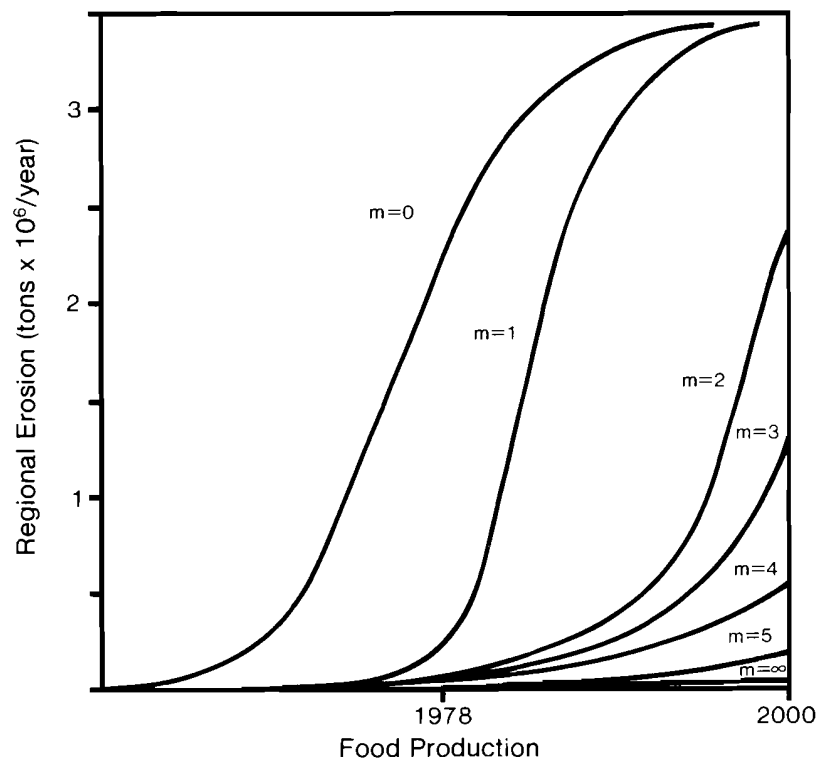

Fig. 9. Minimum possible erosion for the Jalapa region, as it depends upon the quantity of food production. It is assumed that land allocation is optimal for meeting the region's food requirements with minimal erosion. The points " 1978 " and " 2000 " on the horizontal axis represent the amount of food necessary to feed the region in the years 1978 and 2000. The interval between 0 and " 1978 " is a linear interpolation between no food and the food necessary for 1978 . The interval between " 1978 " and " 2000 " is an interpolation between the food production requirements of those years. $m=1$ corresponds to the quantity of agricultural support services available in $1978, \mathrm{~m}=2$ corresponds to double the 1978 quantity and $m=\infty$ indicates unlimited agricultural support services.

Beef production as presently practiced in the Jalapa region is a wasteful use of land. Yields of calories and protein from beef are less per hectare than for any other food-producing land use (Table VIII). As the demand for beef is expected to be high in the year 2000, beef production can be expected to occupy excessive land and force maize production onto hilly areas where erosion will result, unless appropriate planning measures are taken. Fortunately, beef production could be improved drastically, at least five-fold, with the use of better technology, particularly if combined with forage crops. 
This improvement could free tropical land for grain production and allow maize production to be moved away from the hilly and mountainous areas of the temperate zone. These areas would be freed for more appropriate uses, such as forestry, fruit orchards, or well-managed dairy pasture. Fruit trees and pasture would have to be restricted to the gentler slopes, unless they are managed explicitly to limit erosion. The importance of tropical-zone lands for grain production would be their immense scope for improved production because of the possibility of two crops per year with irrigation. Caution would be necessary with irrigation schemes, however, because year-round irrigated agriculture in the tropics may not be sustainable unless it is carefully designed.

Use of marginal tropical land for cattle-forage tree plantations plays a prominent role in the optimal solutions for many scenarios. This land-use system was represented in the Jalapa game by Brossimum alicastrum, a tree whose high-protein seeds and leaves provide excellent cattle forage. This tree is not cultivated in the region but should be tested on a pilot basis in the tropical zone as a promising and ecologically sound means of utilizing marginal lands to increase cattle production.

\section{Environmental costs of increasing food production}

When we looked at how erosion was affected by the level of food production (Fig. 9), from low levels of production up to regional food needs in the year 2000 , it was found that, at a given level of technology, erosion can be quite low until production reaches a threshold. At this point erosion increases considerably because additional and inappropriate land is brought into use. This threshold increases as the level of technology is increased.

In contrast, although the regional load of pesticides and other agricultural chemicals in the environment increases in proportion to the level of production, the chemical load is virtually unaffected by the level of technology used to attain that production. Thus, modern technology is a necessary (though not sufficient) tool for keeping erosion within tolerable bounds as demand for products increases, but such technology does not necessarily imply greater chemical loads on the environment (Table XIII)

The Jalapa region could meet its 1978 production requirements with little erosion; if there were better land use allocation. However, food requirements can be expected to pass the threshold of unavoidably high erosion (Fig. 9) by the year 2000 if technology stays the same. Fortunately, the situation can be corrected by increased inputs of appropriate modern technologies. The necessary increase in modern technology is feasible with sufficient effort.

The land-use game, because it works with optima, presents desirable possibilities. These possibilities can be compared with what is actually happening (Table XI). The erosion occurring in the Jalapa region with land uses that existed in 1978 and 70-times greater than the low level possible if the actual production in 1978 was achieved with an optimal land allocation using 1978 technology (Table XIII). Suboptimal land allocation existed from a soil con- 
servation point of view because individual producers were using the land to satisfy other criteria such as maximizing profits or minimizing the risks and effort involved. Furthermore, implementing optimal land use, whether from an individual or regional point of view, was impeded by socioeconomic constraints such as land tenancy and the availability of technical assistance.

\section{ACKNOWLEDGEMENTS}

The Authors thank the entire staff of INIREB for its support of this work. Dr. Arturo Gomez Pompa (Director of INIREB) and the members of INIREB's Ecological Land-Use Planning Program (Manuel Zola, Enrique Portilla, Arturo Arrieta, Antonieta Lavin, Michael Koterba, Jeronimo Garcia and Lorena Bowser) deserve special mention for their contributions to the ideas and data behind the study. Fernando Brunstein helped to develop the socioeconomic framework of this study and Donald Jameson introduced us to goal programming. Paul Zinke and Jorge Morello instructed the staff in aerial photograph interpretation and land classification; Dr. Zinke conducted nutrient analyses on soil profiles. Sylvio Olivieri contributed to preparation of the final manuscript. We are deeply indebted to the numerous agronomists and farmers of the Jalapa region for the wealth of information they contributed about land use in the region. We also wish to thank the Mexican Department of Agriculture and Water Resources for providing us meteorological and agricultural statistics, as well as numerous officials of the government of the State of Veracruz, Carlos Lascurain and the staff of the Commission for Urban Reform in the Jalapa region for their continuing collaboration. The study was funded by the Ford Foundation, Mexico's National Science and Technology Council, and UNESCO's Man and the Biosphere Program.

\section{REFERENCES}

Bartlett, E.T., Bottoms, K.E. and Pope, R.P., 1976. GOAL-Multiple objective programming. Range Sci. Ser. No. 211, Colorado State University, Fort Collins, $157 \mathrm{pp}$.

Christian, C.S. and Stewart, G.A., 1968. Methodology of integrated surveys. In: Aerial Surveys and Integrated Studies, Proc. Toulousse Conf. UNESCO, Paris, pp. 233-280.

Gomez Pompa, A., 1973. Ecology of the vegetation of Veracruz. In: A. Graham (Editor), Vegetation and Vegetational History of Northern Latin America. Elsevier, New York, pp. 73-148.

Hernandez, M., Chavez, A. and Bourges, H., 1977. Valor nutritivo de los alimentos Mexicanos: Tablas de uso practico. Pub. Div. Nutricion, Inst. Nacional Nutricion, Mexico.

Holdridge, L.R., 1971. Forest Environments in Tropical Life Zones. Pergamon, Oxford, $747 \mathrm{pp}$.

Koterba, M. and Lavin, A., 1979. Metodologia para la clasificacion de climas en la region Jalapa. Rep. Inst. Nacional Investigaciones Recursos Bioticos, Jalapa, Mexico, 54 pp.

Lee, S.M., 1972. Goal Programming for Decision Ánalysis. Petrocelli, New York, 387 pp.

Marten, G.G. and Sancholuz, L.A., 1981a. Estudio ecologico de las zonas cafetaleras de Veracruz, Puebla, Hidalgo y Tamaulipas. Evaluacion estadistica de los muestreos. Biotica, 6: 7-32.

Marten, G.G. and Sancholuz, L.A., 1981b. El maiz como indicador de produccion en el centro do Veracruz. Biotica, 6: 173-180. 
Roumasset, J.A., Boussard, J. and Singh, I. (Editors), 1979. Risk, Uncertainty, and Agricultural Development. Southeast Asian Regional Center for Graduate Study and Research in Agriculture, College, Laguna, Philippines and Agricultural Development Council, New York, $453 \mathrm{pp}$.

Sancholuz, L.A., Marten, G.G. and Zola, M., 1981. Tipos de tierra para la planificacion regional del uso de la tierra. Biotica, 6: 155-172.

University of Veracruz Economics Institute, 1975. Encuesta sobre ingresos y gastos de las familias del estado de Veracruz. Inst. Investigaciones y Estudios Superiores Economicos Sociales, Univ. Veracruzana, Jalapa, Veracruz, Mexico, $110 \mathrm{pp}$.

Wischmeier, W.H., 1974. New developments in estimating water erosion. In: Proc. 29th Annual Meeting Soil Conservation Society of America, 11-14 August 1974. Syracuse, NY, pp. 179-186.

Wischmeier, W.H., 1975. Estimating the soil loss equation's cover and management factor for undisturbed areas. U.S. Dept. Agric., ARS-S-40.

Wischmeier, W.H. and Smith, D.D., 1965. Predicting rainfall-erosion losses from cropland east of the Rocky Mountains - guide for selection of practices for soil and water conservation. Agric. Handbook No. 282, U.S. Dept. Agric., Washington, D.C.

Wischmeier, W.H. and Smith, D.D., 1978. Predicting rainfall erosion losses - a guide to conservation planning. Agric. Handbook No. 537, U.S. Dept. Agric., Washington, D.C.

Wischmeier, W.H. and Mannering, J.V., 1969. Relation of soil properties to its erodibility. Proc. Soil Sci. Soc. Am., 33: 130-137.

Wischmeier, W.H., Johnson, L.B. and Cross, R.V., 1971. A soil erodibility nomograph for farmland and construction sites. J. Soil Water Conserv., 26: 189-193.

Zinke, P., 1981. The use of soil and foliage analysis for rating paisajes in the Jalapa region. Rep. Inst. Nacional Investigaciones Recursos Bioticos, Jalapa, Mexico, 16 pp. 